\title{
Behavior Towards R\&D Investment of Family Firms CEOs: The Role of Psychological Attribute
}

\author{
Muhammad Zulfiqar (D) \\ Rao Zhang ${ }^{2}$ \\ Nazakatullah Khan' \\ Shihua Chen ${ }^{3}$ \\ 'School of Accounting, Dongbei \\ University of Finance and Economics, \\ Dalian, People's Republic of China; \\ ${ }^{2}$ College of Finance, Nanjing Agricultural \\ University, Nanjing, People's Republic of \\ China; ${ }^{3}$ School of Business \\ Administration, Dongbei University of \\ Finance and Economics, Dalian, People's \\ Republic of China
}

Correspondence: Rao Zhang College of Finance, Nanjing Agricultural University

Tel +86-13795/77957

Email zr@njau.edu.cn
Introduction: This study aims to explore the effects of the behavior of chief executive officers (CEOs) within family firms on investment in research and development (R\&D). We also investigate the effect of CEOs' psychological attributes of overconfidence on R\&D investment and the moderating effect between the types of CEOs and R\&D investment.

Methods: We obtained data on Chinese A-share firms from China Stock Exchange and Accounting Research from 2010 to 2018 for analysis. Then, we used the ordinary least squares model for regression results; moreover, the Tobit regression, GMM and firm fixed effect model are applied to check the robustness of the results.

Results: Family CEOs with actual control rights are more open to R\&D investment, whereas those without actual control rights exhibit negative behavior. The study found that nonfamily CEOs exhibit insignificant results and negative predicted signs toward R\&D investment. Moreover, the results show that overconfident CEOs are more inclined to amplify innovation. Furthermore, results on the moderating effects of $\mathrm{CEO}$ psychological attribute of overconfidence indicate that the CEO overconfidence mitigates the negative relationship between family CEOs with actual control rights and R\&D investment. However, no moderating effect is found between family CEOs without actual control and R\&D investment. The CEO psychological attribute behavior is positive between non-family CEOs and R\&D investment.

Discussion: This novel study explores the behavioral effect of different types of family firm CEOs on R\&D investment. This study will assist corporate board members to make more informed decisions about retaining (or bringing back) family CEOs (with or without actual control rights) or hiring non-family CEOs.

Keywords: CEOs types, CEO overconfidence, family firms, R\&D

\section{Introduction}

As a major contributor to the national economy and a crucial factor in emerging markets, family firms have attracted the attention of research scholars in the fields of finance, economics, and management. ${ }^{1,2}$ Typical family firms can be defined as an organization managed and controlled by a set of family members and often passed on to generations. ${ }^{3}$ However, research practitioners on family business defined family firms as a business setup control and run to pursue the vision and mission of founding family members for long-term stability.

The literature on family firms considers innovation as an integral factor for long-term business survival. However, innovation intensity is debatable as it depends on the type of firm. ${ }^{4,5}$ Research practitioners demonstrated dual conclusions regarding the investment of family firms in research and development (R\&D). 
Some research studies exhibited the reluctant behavior of family firms in $R \& D$ investment in terms of preserve socioemotional wealth (SEW) ${ }^{6-8}$ Although R\&D investment exhibits uncertain outcome, this investment enhances firms' long-term performance, ${ }^{9}$ market value, and future growth. ${ }^{9,10}$ On the contrary, the enthusiastic behavior of family firms to escort SEW restrain them to investing in innovation projects. ${ }^{11}$

The extent to which family and non-family members participate in business affairs remains to be answered. The identified that for American firms, the performance of nonfamily firms exceeds that of family firms, but found opposite results. ${ }^{12,13}$ However, for other economies, the results vary. Although not definitely, conflicting outcomes may be subject to the heterogeneity across regions and firms, that is, if they are controlled by family members. Family firms are either managerially operated by family or non-family members. Some of the existing literature stated that family members fail to achieve the desired level of output because of a lack of professionalism and competency. Moreover, family firms fail to bring reforms from traditional management to modern systems because of their lack of managerial abilities. ${ }^{14}$

The business literature of most family firms acknowledged the role of the chief executive officer (CEO) in making strategic decisions, ${ }^{15,16}$ such as investment and resource allocation. ${ }^{17}$ To align with the ongoing changes in the dynamic business environment, the CEOs' role in decision-making is now of great emphasis. ${ }^{18}$ Most scholars urged that the dominance of a powerful CEO may influence decisions regarding the capital structure and leverage choices, ultimately leading to favor of the firm rather than addressing the interest of shareholders. ${ }^{19,20}$

Some studies on family firms suggested that corporate performance divergence exists between family and nonfamily member CEOs. The literature also found that family firm CEOs can run an organization more skillfully than non-family CEOs. ${ }^{21}$ By contrast, Pérez-González ${ }^{22}$ found that family firms having a non-family CEO member perform well than those with a family member CEO. In addition, Galvin, Lange, and Ashforth ${ }^{23}$ stated that the CEO's personality can be measured through the way he leads the firm by making strategic decisions. The personal qualities of a CEO influence the success of an organization, and his ability affects the policy, strategy, and decision-making. ${ }^{24,25}$ CEOs' behavior can be regarded as a predictor of an organization's success. ${ }^{26}$
We focus on family firms and discuss the behavior of family CEOs with and without actual control rights and non-family CEOs without control rights toward firm strategic decision-making. To grasp a better understanding of R\&D innovation investment, we meticulously address the different characteristics of family and non-family firm CEOs in family firm businesses. Specifically, we exploit potential patterns of CEO's overconfidence behavior to determine its impacts on R\&D investment, which is often an unexplored field in the family firm literature.

The rest of the paper is structured as follows. Hypothesis Development provides a literature review and hypothesis development. Sample and Data contains the data, and Results delineates the identification plan and provides summary statistics. Discussion and Conclusion shows the empirical results of the study and a collection of robustness checks. Finally, Section 6 presents the summary and concludes the study.

\section{Agency and Behavioral Agency Theory}

The hypotheses of agency and behavior agency theory are based on greatly different expectations about the efficacy of non-family CEOs in the family business. Agency theory claims that agents are prone to opportunism, except when closely controlled and substantially enhanced to protect the interests of shareholders. ${ }^{27}$ From this theory, family CEOs who are the main stakeholder in the business and whose interests are in accordance with the founder's family will surpass non-family CEOs who are merely agents. $^{28,29}$ In addition, reciprocal outcomes would be expected from behavioral agency practitioners. They concluded that a risk-loving demeanor is a result of prevailing benefits. For instance, family CEOs will avoid intelligent business risks by sacrificing business economic output to protect the SEW that they have invested in their business. ${ }^{11}$ Socioemotional priorities include retaining ownership of family business matters, employing family managers, leveraging business capital, and preventing involvement in uncertain investment ventures. ${ }^{27,30}$ Family CEOs with actual control rights are also more likely to squeeze SEW targets than non-family CEOs without control rights who are less interested in maintaining the interest of the owner.

Behavioral agency theory practitioners argued that certain agents and principals promote nonfinancial goals. ${ }^{31}$ Therefore, ${ }^{11,30}$ maintained that the SEW interests of family members in family businesses - such as maintaining family ownership of the company, risk aversion, and reinforcing 
family members as executives - can counteract financial goals, resulting in poor firm performance. Accordingly, a non-family CEO can negotiate with controlling family individuals with equal formal power and routine organizational obligations, and such SEW goals will equip a non-family CEO with market-oriented steps. ${ }^{21,30}$ Therefore, the tasks of non-family managers would involve supervision by a competent group of key owners whose collective astuteness will preclude opportunism. On the contrary, the theory of behavioral agency, particularly the SEW sub-variety, generally refers to the regular administrative activities of top executives, in which family members are directly involved in such interactions. In this scenario, when working alone, non-family executives would be permitted to financially sacrifice family SEW goals, rather than operating with the consent of family coexecutives.

This study asserts that the theory of agency and behavioral agency has important implications. In addition, the socioemotional viewpoint is a diversity of the theory of behavioral agency that represents certain family executives' non-economic goals. However, this viewpoint is subject to numerous facets of governance and helps to determine exactly when it can outperform non-family CEOs. In particular, agency theory typically refers to wellspaced, regular strategic monitoring interactions and the relationship between agents and firms owners.

\section{Hypothesis Development}

This section comprises arguments regarding the relative merits of non-family CEOs in certain conditions. Using the perspectives of agency and agency behavioral theories, this study will define some general contextual conditions in which non-family CEOs will exhibit better behavior.

\section{Family Firm CEO with Actual Control Rights}

In family firms, family members hold not only the ownership but also the management ${ }^{32}$ according to the equity they possessed. ${ }^{33}$ The reason for holding the management is to participate in the firm's strategic decision. ${ }^{34}$ In family firms, the family CEO's involvement emancipates him to stimulate the firm's R\&D investment decision-making by modeling the firm's objective, tactics, and conducts. ${ }^{35}$ Specifically, a family firm CEO with a higher degree of ownership by holding a greater proportion of equity can take rampant discretion as the owner of the business. ${ }^{36} \mathrm{He}$ can also pose a considerable impact on strategic decisionmaking by his control right. ${ }^{37}$

Similarly, through active participation in management, a family CEO with actual control rights can strengthen his influence on the penetration of the firm by ameliorating the ability to improve firm R\&D investment decisions. ${ }^{36}$ Moreover, a family CEO with actual control rights tends to expand the risk of family firm business by finding innovative strategies to rummage new business areas to generate a positive incentive for innovation. ${ }^{38}$ Family firms create a sense of job security for family members and family managers Zhou, ${ }^{39}$ which in turn induced them ethically to exhibit a robust commitment to the organization. By contrast, in the perspective of the altruism domain, exercising discretionary power helps the family CEO to place them toward the stewardship role. ${ }^{40}$ Family firms experience the advantage of truncated supervision overhead Chrisman, Chua, Kellermanns and Chang, ${ }^{41}$ where family CEOs with control rights can invest in longterm risky innovation projects.

The role of managerial discretion Carney, Zhao, $\mathrm{Zhu}^{42}$ which is quite significant in family firms, is emphasized in the upper echelon. Moreover, upper echelons theory ascertains equity ownership as a feature of "managerial discretion" that is alleged to exaggerate the impact of executives' psychological physiognomies on their strategic decision-making and implementation. ${ }^{43}$ The objective is to ensure that the top management team of the company bases its strategic decision on its understanding and environmental interpretation. Furthermore, the upper echelons forecast that the managers' understandings and interpretations are molded by demographic features, such as age, gender, and education career, including other life experiences. ${ }^{44}$ As a means to understand strategic decision-making in family firms in the Western culture Carney, Zhao, $\mathrm{Zhu}^{42}$ the upper echelons are increasingly applied but heretofore have not been used in progressive institutional settings, such as China, which is a research lacuna known as "black box". 45

This study considers family firm CEOs with and without actual control right as different identities and examines their behavior regarding the R\&D investment decision. Our H1a and H1b hypotheses in this case are as follows:

H1a. Family firm CEOs with actual control rights have more inclined behavior toward R\&D investment. 
H1b. Family firm CEOs without actual control rights have less willingness toward R\&D investment.

\section{Family Firms with Non-Family CEO}

The literature usually identified that a firm operated by family CEOs is substandard regarding performance contrary to a firm managed by non-family CEOs. ${ }^{46}$ The literature ascribed this performance deficit to family members' deficiency of managerial expertise ${ }^{47}$ and vicious power battles among descendants. However, Chinese family firms are unique from family firms operating in Western economies. Primarily, a large part of Chinese family businesses are relatively under strict control of firms' founders, and the power squabbles are less. ${ }^{48}$ Even if the organization is run by the succeeding generation, their executive expertise is more professional as knowledge sharing about business affairs from the founder CEOs can be easily transmitted into their children compared with that from non-family CEOs. ${ }^{40}$ Moreover, the imperfect nature of the Chinese managerial market can cause troubles in organizing non-family CEOs. Subsequently, the interest of shareholders is readily harmed by non-family CEOs.

Initially, in non-family CEOs who hold a little fraction of firm shares, their main economic advantages are financial rewards, managerial labor market status, and invisible benefits. ${ }^{41}$ However, they can turn to avail more latent benefits due to the deficiency constraints of the managerial labor market and the equity-based incentive approach in China. To increase their utility, they may eschew their financial outcomes. ${ }^{40}$ However, the uncertainty suits them to gain additional personal favors through ineffectual investment because instead of their incompetent investment decision, they may attribute the consequence of their decision to uncertainty. ${ }^{42}$ On the contrary, family CEOs behave more as guardians than agents in the service of firms. ${ }^{41}$ Their key economic advantages as the founder or heirs are expressed in the maximization of firm value. The underlying concept is that the connections between the current and future generations provide "patient capital" to family businesses, which is an emphasis on optimizing long-term returns and the ability to seek investment opportunities. $^{40}$

Moreover, according to the resource-based view, in emerging economies having substandard institutional structures, accessibility to resources mostly occurs through certain privately informal networks rather than formal channels. $^{43}$ The family ties factor also provides a competitive advantage to family CEOs over non-family ones regarding their access to specific resources (ie, in business groups, some resources are accessible specifically to family CEOs instead of non-family CEOs). ${ }^{44}$ Therefore, compared with the investment of non-family CEOs escalating their benefits, the investment of family CEOs is focused on optimizing the productivity of resource utilization. Family CEOs sustain profound alignment of interest with family owners, and such family relations will minimize the agency cost between directors and agents. ${ }^{45}$ Thus, we propose the following:

H1c. Non-family CEOs in family firms have less willingness toward R\&D investment.

\section{CEO Overconfidence and R\&D}

\section{Investment}

Overconfidence is a psychological phenomenon, which induces CEOs to take extraordinary strategic decisions that ultimately influence organizational outcomes. Under this phenomenon, an individual is buoyant on his decisions, which befalls in three ways. First, an individual overestimates his abilities. Second, an overconfident individual considers himself better than others. Finally, an overconfident individual is certain about the precision of his beliefs. ${ }^{49,50}$ These three biases in psychology are called miscalibration, above-average effect, and the illusion of control, respectively. ${ }^{51}$ Overconfident behavior leads the CEO to make an overinvestment in riskier projects whose outcomes are uncontrollable to avoid risk in the failure. ${ }^{52}$ Similarly, Campbell and Guttel ${ }^{53}$ defined psychology overconfidence as the propensity to make more precise forecasting than what an actual probability distribution would warrant; psychology overconfidence would be more likely to take more risk. By contrast, in the finance literature, overconfidence is often a substitute for dubious optimism or wishful thinking to make a more accurate prediction of future outcomes. ${ }^{53}$ Chen, $\mathrm{Ho}, \mathrm{Ho}^{54}$ showed that $\mathrm{CEO}$ overconfidence has a false tendency in determining the level of investment risk and does not cause a positive impact on the firm's efficiency. Excess CEO overconfidence can create a negative impression on firm productivity because the CEO adopts a risky, inefficient, or false investment policy that ends up determining the risks and returns on some investments. ${ }^{51} \mathrm{CEO}$ overconfidence tends to overestimate the return on investment and underestimate risks. ${ }^{52}$ However, several other research showed different results, where CEO overconfidence tends to lead to 
optimism about future firm performance and thus overestimates the firm's ability to create future earnings. ${ }^{55}$ Moreover, overconfident CEOs overestimate their ability to invest in riskier $\mathrm{R} \& \mathrm{D}$ projects, with a miscalculation of hatching anticipated outcomes. ${ }^{51}$ However, overconfident CEOs remain reluctant to invest in information assortment about projects that ultimately lead to unproductive investments. ${ }^{56}$ In some worse cases, the overconfidence behavior of CEOs leads to financial distress and subsequently financial misstating and fraud. However, CEOs' overconfidence behavior keeps them optimistic regarding forthcoming outcomes. ${ }^{57}$ The results of prior research suggest differences in findings that encourage the question of whether CEO overconfidence improves firm performance through innovation and investment strategies or whether overconfidence will degrade the firm's performance in the next years because of the high risks and expectations of an investment that may be mistaken. Based on the foregoing, this research hypothesis is proposed as follows:

$\mathrm{H} 2$. Overconfident CEOs are more willing toward R\&D investment.

\section{Family Firm CEO Overconfidence and R\&D Investment}

Although CEO overconfidence behavior is prevalent, overconfidence notch varies. Overconfidence is affected not only by the task's characteristics but also by different abilities, particularly in the fields where experience and expertise are crucial to success. ${ }^{58}$ The cognitive difference created by overconfidence is rooted in the illusion of control from a psychological perspective. ${ }^{59}$ That is, people are greatly convinced that the outcome of future proceedings can be controlled. When individuals have more decision-making authority, the illusion of control is more evident. In a company, management discretion affects the extent to which CEOs are involved in sound decisions and results, and is vital for the illusion of control. ${ }^{60}$ Management discretion allows managers more choices and upsurges the trend toward overconfidence and their impact on managers. By contrast, some restraint in the trend toward over-confidence and its effects exists where vigorous monitoring and mediation also exists. ${ }^{61}$ Therefore, management discretion would affect the influence of CEO overconfidence on firm strategic decisionmaking. In companies, as the owners, shareholders approve the agent to manage the business. The board of directors is established to oversee the conduct of the CEO to reduce the issue of the agency. Its help lessens the conflict among agencies and diminishes the CEO's authority, which may affect the influence of overconfidence on the strategic decision-making of the company through supervision by the board. ${ }^{62}$

Similarly, the tendency of the CEO to undertake R\&D projects will be diminished by the existence of a family firm, particularly if the CEO is having actual control rights of the firms. Family firms will incline toward lowlevel R\&D investment because of a strong sense of ownership of the firms. The reason is that family firms want to maintain the socio-economic wealth and family reputation. ${ }^{29}$ Moreover, Block ${ }^{63}$ indicated that family firm CEOs with actual control right tend to invest heavily in R\&D activities. However, the intensity of family firms in $R \& D$ activities is lower than that of other firms because of the tradeoff of declining welfare short-term economic benefits. ${ }^{6,8,52}$ Then, R\&D investment is considered sunk costs having an extended payoff horizon with substantial risk attachment. ${ }^{64}$ In addition, failed investment attempt will not only damage the firm's reputation but also diminish the SEW of family firms. ${ }^{65}$ Family firms are much committed to maintaining the long-run sustainability of the firm by avoiding things that can negatively affect the firm. Similarly, Alqatamin, Aribi and Arun $^{66}$ revealed that family firms incline to do SEW protection contrary to non-family firms. The reason is that family firms and family firm CEOs with actual control over the management and high access to information on the firm can maximize personal benefits and avoid R\&D investment. ${ }^{2}$ By contrast, family firm CEOs without actual control right possessing overconfidence traits will tend to invest more in riskier long-term R\&D projects. Excess CEO overconfidence trait compels him/her to adopt a risky and uncertain investment policy that ends up determining the risks and returns on some investment. ${ }^{51,67} \mathrm{CEO}$ overconfidence tends to overestimate the return on investment and underestimate risks. ${ }^{52}$ From the above discussion, we can conclude that family firm CEOs with actual control and the overconfident trait will emerge a strong sense of ownership, which will avoid them from investing in R\&D activities. However, family firm CEOs without actual control right but with overconfidence behavior will tend to have a positive effect on R\&D investment. Hence, the following hypotheses are proposed: 
Table I Mean Comparison

\begin{tabular}{|c|c|c|c|c|c|c|c|c|c|}
\hline Variables & Others & $\begin{array}{l}\text { Non- } \\
\text { Family } \\
\text { CEO }\end{array}$ & $\begin{array}{l}\text { T-Test } \\
\text { Score }\end{array}$ & Other & $\begin{array}{l}\text { Family } \\
\text { CEO \& } \\
\text { Controller }\end{array}$ & $\begin{array}{l}\text { T-Test } \\
\text { Score }\end{array}$ & Other & $\begin{array}{l}\text { Family CEO } \\
\text { \& Non- } \\
\text { Controller }\end{array}$ & $\begin{array}{l}\text { T-Test } \\
\text { Score }\end{array}$ \\
\hline R\&D Investment & 0.0127 & 0.0109 & $1.70 * *$ & 0.0102 & 0.0141 & $-3.68 * * *$ & 0.0123 & 0.0042 & $3.89 * * *$ \\
\hline CEO Overconfidence & 0.2220 & 0.3643 & $-13.38 * * *$ & 0.3507 & 0.2167 & $12.19 * * *$ & 0.3063 & $0.248 I$ & $2.86^{* * *}$ \\
\hline Leverage & 0.3265 & 0.4093 & $-20.93 * * *$ & 0.4055 & 0.3182 & $21.72^{* * *}$ & 0.3699 & 0.3759 & -0.75 \\
\hline No. of Board Meeting & 9.2176 & 9.9917 & $-10.5 \mid * * *$ & 9.8350 & 9.3212 & $6.84 * * *$ & 9.7015 & 8.5893 & $7.53^{* * *}$ \\
\hline ROE & 0.0808 & 0.0679 & $6.01 * * *$ & 0.0687 & 0.0818 & $-6.01 * * *$ & 0.0739 & 0.0748 & -0.21 \\
\hline Firm Age & 4.2218 & 7.9369 & $-33.13 * * *$ & 7.6742 & 3.9916 & $32.29 * * *$ & 6.1869 & 5.6415 & $2.31 * *$ \\
\hline $\begin{array}{l}\text { Independent Director } \\
\text { Ratio }\end{array}$ & 0.3792 & 0.3703 & $8.76 * * *$ & 0.3704 & 0.3805 & $-9.71 * * *$ & 0.3747 & 0.3716 & $1.65^{*}$ \\
\hline Size & 21.2941 & 21.3941 & $-5.10 * * *$ & 21.4021 & 21.2653 & $6.85 * * *$ & 21.3389 & 21.4656 & $-3.24 * * *$ \\
\hline Institutional_Shareholding & 5.2678 & $5.680 \mathrm{I}$ & $-3.7 \mid * * *$ & 5.5921 & 5.3298 & $2.3 I^{* *}$ & 5.5289 & 4.8942 & $2.85^{* *}$ \\
\hline Board Size & 8.2407 & 8.4157 & $-6.17 * * *$ & 8.415 & 8.2115 & $7.07^{* * *}$ & 8.3412 & 8.4433 & $-1.74 *$ \\
\hline Is_Chairman_Family & 1.0078 & 0.6711 & $41.84 * * *$ & 0.7235 & 0.9849 & $-30.92 * * *$ & 0.8058 & I. 1472 & $-19.99 * * *$ \\
\hline CEO_Tenure & 6.2171 & 5.0190 & $15.23 * * *$ & 5.1066 & 6.2353 & $-13.84 * * *$ & 5.4469 & 6.1043 & $-3.80 * * *$ \\
\hline CEO Pay & 12.5437 & 12.4940 & $3.60 * * *$ & 12.4889 & 12.5594 & $-5.01 * * *$ & 12.5222 & 12.4486 & $2.65^{* * *}$ \\
\hline CEO Power & 0.2375 & 0.2297 & $4.48 * * *$ & 0.2289 & $0.240 I$ & $-6.34 * * *$ & 0.2341 & 0.2224 & $3.40^{* * *}$ \\
\hline
\end{tabular}

Note: *Shows significance level. ***, **, and $*$ Indicates $\mathrm{P}<1 \%, 5 \%$, and $10 \%$.

H3a. Family firm CEOs with actual control right in the case of overconfident behavior as moderating factor will tend to negatively affect R\&D investment.

H3b. Family firm CEOs without actual control right in the case of overconfident behavior as moderating factor will tend to positively affect R\&D investment.

\section{Non-Family CEO Overconfidence and R\&D Investment}

To examine the influence of a powerful CEO on firm innovation agenda, CEO origin, that is, whether he is a family member or otherwise, should be also considered. Family and non-family business literature uphold that nonfamily company CEOs typically bring new ideas and a fresh viewpoint with them, whereas family company CEOs normally have company-specific expertise gained from their experience within the company. Thus, the origin of the CEO may affect the innovation activities of an organization. Historical research indicated that companies are more likely to select outside CEOs when change is needed Zhang, Rajagopalan ${ }^{68}$ because new or different strategies are expected to be pursued by these CEOs. ${ }^{69}$ By examining the differences between family CEOs and non-family CEOs, Zhang, Rajagopalan ${ }^{68}$ showed that the relationship between the level of strategic change and the performance of the company differs between companies led by family and non-family CEOs. In particular, companies headed by non-family CEOs are found to have more pronounced levels of strategic transition. Zhang and Rajagopalan ${ }^{68}$ further stated that non-family CEOs would often stray rather than expand the existing capabilities of the business due to their limited knowledge of the existing resources and constraints of the company. This result shows that non-family CEOs are best suited to exploratory innovation. ${ }^{70}$

Furthermore, as non-family CEOs hold the knowledge that is "new" to a firm, they are aware of the corresponding risks of losing market share to opponents if new products are not introduced. Profound literature argued that overconfident CEOs' level of innovation increases. ${ }^{71}$ Several explanations exist for this relation. The first explanation exists through the overestimation of CEOs' ability and their certainty regarding the 
Table 2 Descriptive Analysis

\begin{tabular}{|c|c|c|c|c|c|}
\hline Variables & Mean & Std. Dev. & Min & Max & VIF \\
\hline R\&D Investment & 0.011799 & 0.0504 & 0 & 0.402023 & \\
\hline Family CEO \& Controller & 0.400928 & 0.490108 & 0 & I & 1.80 \\
\hline Family CEO \& Non-controller & 0.06599 & 0.248275 & 0 & I & 1.20 \\
\hline Non-family CEO & 0.533082 & 0.498926 & 0 & 1 & 1.04 \\
\hline CEO Overconfidence & 0.302027 & 0.459168 & 0 & 1 & 1.06 \\
\hline Leverage & 0.370338 & 0.205617 & 0.046011 & $0.86008 \mathrm{I}$ & 1.80 \\
\hline No. of Board Meeting & 9.627486 & 3.917045 & 0 & 44 & 1.21 \\
\hline ROE & 0.073988 & 0.114391 & -0.51967 & 0.455307 & 1.14 \\
\hline Firm Age & 6.150333 & 5.873582 & 0 & 22 & 1.73 \\
\hline Independent Director Ratio & 0.374522 & 0.052052 & 0.333333 & $0.57 \mid 429$ & 1.47 \\
\hline Size & 21.34741 & 1.00412 & 18.81058 & 24.25099 & 1.57 \\
\hline Institutional_Shareholding & 5.486553 & 5.196521 & 0.12 & 26.519 & 1.09 \\
\hline Board Size & 8.333365 & 1.443995 & 5 & 12 & 1.55 \\
\hline Is_Chairman_Family & 0.828374 & 0.460847 & 0 & I & 1.19 \\
\hline CEO_Tenure & 5.482291 & 3.121055 & 1 & 14 & 1.70 \\
\hline CEO Pay & 12.51734 & 0.73464 & 10.59663 & 14.35347 & 1.49 \\
\hline CEO Power & 0.233364 & 0.080283 & 0 & 0.486203 & 1.57 \\
\hline
\end{tabular}

accuracy of their beliefs. In addition to overestimating their abilities and beliefs, they overestimate the returns of projects they invest in. Therefore, overconfident CEOs invest more. ${ }^{52}$

However, recently, two scholars revealed the positive influence of overconfident CEOs on firm innovation capabilities. ${ }^{60}$ Overconfident behavior leads an individual to expect substantial outcomes, and simultaneously, they overestimate their capabilities and audacious to certainly accomplish hard tasks (Griffin and Tversky). ${ }^{72}$ Hardly surprisingly, overconfident CEOs mold themselves to be much enthusiastic about uncertain, daring $R \& D$ projects as compared to pessimistic CEOs.

Given the above differences among family and nonfamily CEOs, this study suggests that overconfident CEOs without actual control rights but have overconfident trait will engage in more R\&D innovations. As such, the following hypothesis is presented:
H3c. Non-family CEOs in family firms without actual control right in the case of overconfident behavior as a moderating factor will tend to positively affect R\&D investment.

\section{Sample and Data}

The study focused on different types of CEOs in family businesses and collected data from the China Stock Exchange and Accounting Research (CSMAR). The study collected data of A-share firms listed on the Shenzhen Stock Exchange and the Shanghai Stock Exchange. The CSMAR is a comprehensive and appropriate database for publicly available Chinese companies. ${ }^{42}$ We excluded all firms owned by SOEs and firms with missing values of total revenues, assets, and liabilities. The data used are from 2010 to 2018 and included 5369 observations. The study used the winsor 2 method at $1 \%$ and $99 \%$ to remove outlier and used the same approach used by many scholars to remove extreme values. ${ }^{42}$ In 


\begin{tabular}{|c|}
\hline$\stackrel{8}{-}$ \\
\hline$\stackrel{8}{\stackrel{*}{*}} \stackrel{i}{i}$ \\
\hline 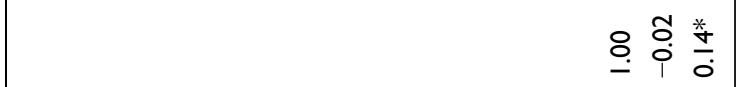 \\
\hline 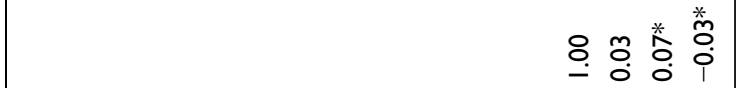 \\
\hline 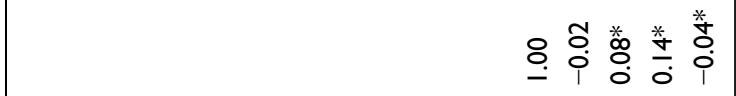 \\
\hline 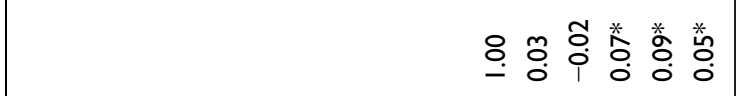 \\
\hline 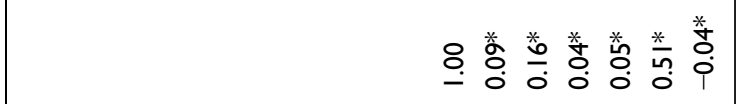 \\
\hline 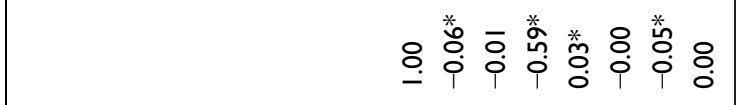 \\
\hline 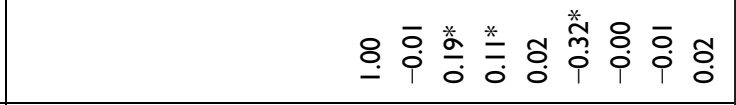 \\
\hline 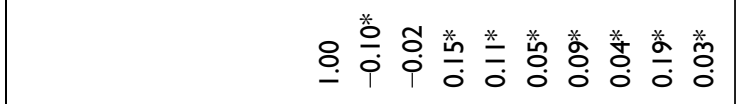 \\
\hline o \\
\hline 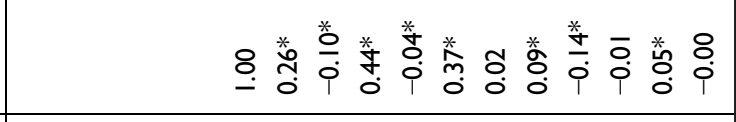 \\
\hline 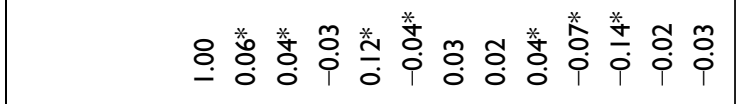 \\
\hline 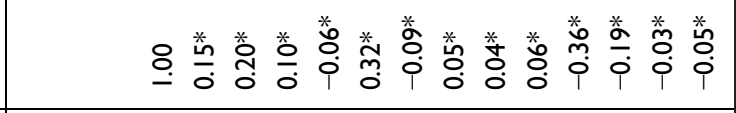 \\
\hline 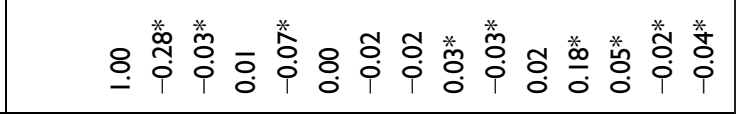 \\
\hline 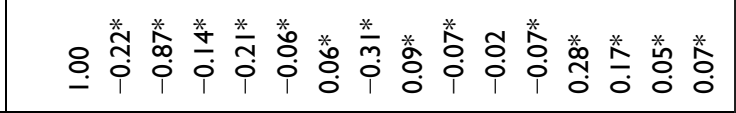 \\
\hline 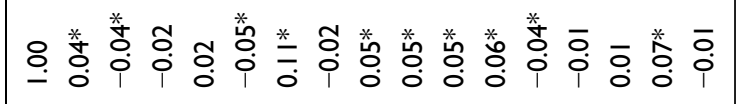 \\
\hline 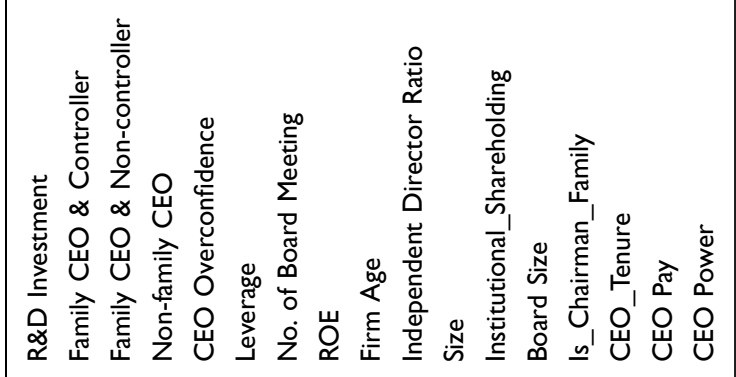 \\
\hline
\end{tabular}


Table 4 Regression Outcomes

\begin{tabular}{|c|c|c|c|c|}
\hline \multirow[t]{2}{*}{ Variables } & MI & M2 & M3 & M4 \\
\hline & R\&D & R\&D & R\&D & R\&D \\
\hline Family CEO \& Controller & $\begin{array}{l}0.0042 I^{* *} \\
(0.00194)\end{array}$ & & & \\
\hline Family CEO \& Non-controller & & $\begin{array}{c}-0.00443^{* *} \\
(0.00264)\end{array}$ & & \\
\hline Non-family CEO & & & $\begin{array}{l}-0.00258 \\
(0.00186)\end{array}$ & \\
\hline CEO Overconfidence & & & & $\begin{array}{l}0.00459 * \\
(0.00255)\end{array}$ \\
\hline Leverage & $\begin{array}{c}-0.03810 * * * \\
(0.00708)\end{array}$ & $\begin{array}{c}-0.03290 * * * * \\
(0.00662)\end{array}$ & $\begin{array}{c}-0.03790 * * * \\
(0.00727)\end{array}$ & $\begin{array}{c}-0.04570 * * * \\
(0.00913)\end{array}$ \\
\hline No. of Board Meeting & $\begin{array}{c}0.00150 * * * \\
(0.00035)\end{array}$ & $\begin{array}{c}0.00136 * * * \\
(0.00032)\end{array}$ & $\begin{array}{c}0.00150 * * * \\
(0.00036)\end{array}$ & $\begin{array}{l}0.00072 * * \\
(0.00028)\end{array}$ \\
\hline ROE & $\begin{array}{c}-0.03130 * * * \\
(0.00906)\end{array}$ & $\begin{array}{c}-0.01870^{* *} \\
(0.00739)\end{array}$ & $\begin{array}{c}-0.02710^{* * *} \\
(0.00842)\end{array}$ & $\begin{array}{c}-0.02870^{* * * *} \\
(0.01010)\end{array}$ \\
\hline $\begin{array}{l}\text { Firm Age } \\
\text { Independent Director Ratio }\end{array}$ & $\begin{array}{c}0.00123 * * * \\
(0.00029) \\
0.00392 \\
(0.02030)\end{array}$ & $\begin{array}{c}0.0009 I^{* * *} \\
(0.00027) \\
0.02250 \\
(0.02020)\end{array}$ & $\begin{array}{c}0.00111 \text { I*** } \\
(0.00029) \\
0.02390 \\
(0.02100)\end{array}$ & $\begin{array}{c}0.00102^{* * *} \\
(0.00034) \\
0.02110 \\
(0.0233)\end{array}$ \\
\hline Size & $\begin{array}{l}0.00267 * \\
(0.00146)\end{array}$ & $\begin{array}{c}0.00124 \\
(0.00134)\end{array}$ & $\begin{array}{c}0.00243 \\
(0.00151)\end{array}$ & $\begin{array}{l}0.00422 * * \\
(0.00178)\end{array}$ \\
\hline Institutional_Shareholding & $\begin{array}{l}0.00048 * * \\
(0.00020)\end{array}$ & $\begin{array}{c}0.00028 \\
(0.00018)\end{array}$ & $\begin{array}{l}0.00040 * * \\
(0.00020)\end{array}$ & $\begin{array}{c}0.00004 \\
(0.00021)\end{array}$ \\
\hline Board Size & $\begin{array}{l}-0.00132 \\
(0.00090)\end{array}$ & $\begin{array}{l}-0.00063 \\
(0.00086)\end{array}$ & $\begin{array}{l}-0.00070 \\
(0.00093)\end{array}$ & $\begin{array}{l}-0.00161 \\
(0.00109)\end{array}$ \\
\hline Is_Chairman_Family & $\begin{array}{c}-0.00692 * * * \\
(0.00209)\end{array}$ & $\begin{array}{c}-0.00416^{* *} \\
(0.00203)\end{array}$ & $\begin{array}{c}-0.00724 * * * \\
(0.00227)\end{array}$ & $\begin{array}{c}-0.00709 * * * \\
(0.00248)\end{array}$ \\
\hline CEO_Tenure & $\begin{array}{l}-0.00040 \\
(0.00032)\end{array}$ & $\begin{array}{l}-0.00015 \\
(0.00032)\end{array}$ & $\begin{array}{l}-0.00032 \\
(0.00033)\end{array}$ & $\begin{array}{l}-0.00004 \\
(0.00037)\end{array}$ \\
\hline CEO Pay & $\begin{array}{l}-0.00001 \\
(0.00170)\end{array}$ & $\begin{array}{l}-0.00076 \\
(0.00152)\end{array}$ & $\begin{array}{l}-0.00048 \\
(0.00172)\end{array}$ & $\begin{array}{l}-0.00184 \\
(0.00196)\end{array}$ \\
\hline CEO Power & $\begin{array}{l}-0.00102 \\
(0.01190)\end{array}$ & $\begin{array}{l}-0.00537 \\
(0.01040)\end{array}$ & $\begin{array}{c}0.00176 \\
(0.01140)\end{array}$ & $\begin{array}{l}-0.00811 \\
(0.01260)\end{array}$ \\
\hline Constant & $\begin{array}{c}-0.04650 * \\
(0.02640)\end{array}$ & $\begin{array}{l}-0.01970 \\
(0.02610)\end{array}$ & $\begin{array}{l}-0.04610 \\
(0.02820)\end{array}$ & $\begin{array}{l}-0.04310 \\
(0.03180)\end{array}$ \\
\hline $\begin{array}{l}\text { Year } \\
\text { Industry } \\
\text { R-squared }\end{array}$ & $\begin{array}{c}\text { Yes } \\
\text { Yes } \\
0.105\end{array}$ & $\begin{array}{c}\text { Yes } \\
\text { Yes } \\
0.082\end{array}$ & $\begin{array}{l}\text { Yes } \\
\text { Yes } \\
0.110\end{array}$ & $\begin{array}{l}\text { Yes } \\
\text { Yes } \\
0.101\end{array}$ \\
\hline
\end{tabular}

Notes: Robust standard errors are in parenthesis. *Shows significance level. ***, **, and *Indicates $P<1 \%, 5 \%$, and $10 \%$. 
Table 5 Regression Outcomes

\begin{tabular}{|c|c|c|c|}
\hline \multirow[t]{2}{*}{ Variables } & M5 & M6 & M7 \\
\hline & $\mathbf{R} \& \mathbf{D}$ & $\mathbf{R} \& \mathbf{D}$ & $\mathbf{R} \& \mathbf{D}$ \\
\hline Family CEO \& Controller & $\begin{array}{c}0.00789 * * * \\
(0.00255)\end{array}$ & & \\
\hline Family CEO \& Non-controller & & $\begin{array}{l}-0.00270 \\
(0.00216)\end{array}$ & \\
\hline Non-family CEO & & & $\begin{array}{c}-0.00707^{* * * *} \\
(0.00253)\end{array}$ \\
\hline CEO Overconfidence & $\begin{array}{c}0.00980 * * * \\
(0.0033 \mathrm{I})\end{array}$ & $\begin{array}{l}0.00450 * \\
(0.00258)\end{array}$ & $\begin{array}{c}-0.00608^{* *} \\
(0.00295)\end{array}$ \\
\hline Family CEO \& controller X CEO overconfidence & $\begin{array}{c}-0.01820 * * * \\
(0.00401)\end{array}$ & & \\
\hline Family CEO \& non-controller X CEO overconfidence & & $\begin{array}{c}0.00224 \\
(0.00828)\end{array}$ & \\
\hline Non-family CEO X CEO overconfidence & & & $\begin{array}{c}0.01620^{* * * *} \\
(0.00445)\end{array}$ \\
\hline Leverage & $\begin{array}{c}-0.04500^{* * *} \\
(0.0091 \mathrm{I})\end{array}$ & $\begin{array}{c}-0.04570^{* * *} \\
(0.00910)\end{array}$ & $\begin{array}{c}-0.04540 * * * \\
(0.00913)\end{array}$ \\
\hline No. of Board Meeting & $\begin{array}{l}0.00068 * * \\
(0.00028)\end{array}$ & $\begin{array}{l}0.0007 I^{* *} \\
(0.00028)\end{array}$ & $\begin{array}{l}0.00066 * * \\
(0.00028)\end{array}$ \\
\hline ROE & $\begin{array}{c}-0.02830^{* * * *} \\
(0.01010)\end{array}$ & $\begin{array}{c}-0.02860^{* * *} \\
(0.01010)\end{array}$ & $\begin{array}{c}-0.02880^{* * * *} \\
(0.01010)\end{array}$ \\
\hline Firm Age & $\begin{array}{c}0.00105^{* * *} \\
(0.00035)\end{array}$ & $\begin{array}{c}0.00102 * * * \\
(0.00034)\end{array}$ & $\begin{array}{c}0.00108^{* * * *} \\
(0.00035)\end{array}$ \\
\hline Independent Director Ratio & $\begin{array}{c}0.01340 \\
(0.02310)\end{array}$ & $\begin{array}{c}0.02130 \\
(0.02360)\end{array}$ & $\begin{array}{c}0.01230 \\
(0.02330)\end{array}$ \\
\hline Size & $\begin{array}{c}0.00427^{* *} \\
(0.00180)\end{array}$ & $\begin{array}{c}0.00419 * * \\
(0.00178)\end{array}$ & $\begin{array}{c}0.00445 * * \\
(0.00180)\end{array}$ \\
\hline Institutional_Shareholding & $\begin{array}{c}0.00002 \\
(0.00021)\end{array}$ & $\begin{array}{c}0.00004 \\
(0.00021)\end{array}$ & $\begin{array}{c}0.00003 \\
(0.0002 I)\end{array}$ \\
\hline Board Size & $\begin{array}{c}-0.00179 * \\
(0.00108)\end{array}$ & $\begin{array}{l}-0.00160 \\
(0.00109)\end{array}$ & $\begin{array}{c}-0.00184 * \\
(0.00108)\end{array}$ \\
\hline Is_Chairman_Family & $\begin{array}{c}-0.00740^{* * *} \\
(0.0025 \mathrm{I})\end{array}$ & $\begin{array}{c}-0.00696^{* * *} \\
(0.00260)\end{array}$ & $\begin{array}{c}-0.00716^{* * * *} \\
(0.00260)\end{array}$ \\
\hline CEO_Tenure & $\begin{array}{l}-0.00022 \\
(0.00037)\end{array}$ & $\begin{array}{l}-0.00003 \\
(0.00037)\end{array}$ & $\begin{array}{l}-0.00020 \\
(0.00037)\end{array}$ \\
\hline CEO Pay & $\begin{array}{l}-0.00175 \\
(0.00196)\end{array}$ & $\begin{array}{l}-0.00182 \\
(0.00196)\end{array}$ & $\begin{array}{l}-0.00194 \\
(0.00196)\end{array}$ \\
\hline CEO Power & $\begin{array}{l}-0.00799 \\
(0.01270)\end{array}$ & $\begin{array}{l}-0.00825 \\
(0.01260)\end{array}$ & $\begin{array}{l}-0.00832 \\
(0.01260)\end{array}$ \\
\hline Constant & -0.04210 & -0.04300 & -0.03580 \\
\hline
\end{tabular}

(Continued) 
Table 5 (Continued).

\begin{tabular}{|l|c|c|c|}
\hline \multirow{2}{*}{ Variables } & M5 & M6 & M7 \\
\cline { 2 - 4 } & R\&D & R\&D & $(0.03240)$ \\
\hline Year & $(0.03230)$ & Yes & Yes \\
\hline Industry & Yes & Yes & Yes \\
\hline R-squared & Yes & 0.101 & 0.106 \\
\hline
\end{tabular}

Notes: Robust standard errors are in parenthesis. *Shows significance level. ***, **, and *Indicates $P<1 \%, 5 \%$, and $10 \%$.

addition, this study reduced the probable biases in the empirical model from omitted variables and endogeneity by applying these two actions. First, the year and industry effect are controlled by creating dummies of both, and second, a 1-year lag on all independent variables is taken.

The CEO type variables used in this study are the dichotomous variable, and normally, most CEOs do not change their status over the period. Thus, this study opted to use the pooled regression model for the outcomes.

\section{CEO Type}

Our independent variable is the CEO type, and we introduce three types of CEOs within family firms as follows: (1) CEOs from family and the actual controller of the family firm; (2) CEOs from family but not an actual controller of the family firm; (3) CEOs hired from outside the family.

\section{CEO Overconfidence}

The overconfidence attribute of CEOs can be measured in a number of ways. Some of the preceding literature used media reportage, ${ }^{73,74}$ numbers of company's options retained by the $\mathrm{CEO},{ }^{52,74}$ partialities among managers' forecasted and actual earnings, ${ }^{75}$ merger and acquisition (M\&A) frequencies introduced by the $\mathrm{CEO},{ }^{74}$ existing firm performance, ${ }^{76}$ and salaries of CEOs' family members.

This study has constructed two sets of proxies measuring the executives' overconfidence on the basis of data availability and the financial position of listed companies on the Chinese stock exchange. The first indicator is the gap between estimated earnings and actual earnings of the top executives, which notable if the forecasted value of actual earnings is over the forecasted value. This study uses the over forecast (ie, estimated earnings are higher than real earnings) higher frequency as an indicator to determine the overconfidence nature of the top executives for the entire sample period.

Confidence-1 is a static measure in this context comprising one observation per firm or top executive. This approach was applied by $\mathrm{Lin}, \mathrm{Hu}, \mathrm{Chen}^{75}$ in Taiwanese data. They established that CEOs with overconfident nature are inclined to overestimate their forecasted returns and this disparity between estimated and actual returns can be used to identify as a CEO's overconfidence index. This overconfidence measures validity, and authenticity was confirmed by employing robustness tests. Moreover, this overconfidence proxy was used by $\mathrm{Li}$ and $\mathrm{Tang}^{77}$ in Chinese data whereas Hribar and Yang $^{73}$ used a similar approach for the US data set. Both concluded that overconfident CEOs more frequently overestimate firms' earnings in their prediction, indicating that the overconfidence proxy based on earnings forecast is a robust indicator.

The CSRC released a set of regulations to limit the biases in earnings forecasts to avoid listed companies from submitting biased (particularly over-biased) earnings forecasts to manipulate stock prices. For instance, if the gap between expected and actual earnings exceeds $10 \%$, then the listed firms and their accounting firms will be held accountable. Certainly, any knowingly upwardly skewed earnings outlook should be drastically diminished by this penalty. The overconfidence behavior of managers usually plays a critical role in certain firms having overestimated profits. This study selected those firms that have revealed quarterly and annual income estimates in their performance reports for the corresponding period. The category of earnings forecast comprises expected loss, expected revenues, expected positive and negative returns, and others. Some firms announced precise ranges of adjustments, such as "may increase by more than $50 \%$ " or "increase from 50 to $100 \%$ " with regard to the anticipated 
Table 6 Regression Outcomes with R\&D Assets

\begin{tabular}{|c|c|c|c|c|}
\hline \multirow[t]{2}{*}{ Variables } & M8 & M9 & MIO & MII \\
\hline & $\mathbf{R} \& \mathbf{D}$ & R\&D & $\mathbf{R} \& \mathbf{D}$ & $\mathbf{R} \& \mathbf{D}$ \\
\hline Family CEO \& Controller & $\begin{array}{l}0.00050 * * \\
(0.00024)\end{array}$ & & & \\
\hline Family CEO \& Non-controller & & $\begin{array}{c}-0.00136 * * * \\
(0.00031)\end{array}$ & & \\
\hline Non-family CEO & & & $\begin{array}{l}-0.00012 \\
(0.00023)\end{array}$ & \\
\hline CEO Overconfidence & & & & $\begin{array}{c}0.00003 \\
(0.00024)\end{array}$ \\
\hline Leverage & $\begin{array}{c}-0.00357 * * * \\
(0.00063)\end{array}$ & $\begin{array}{c}-0.00378 * * * \\
(0.00065)\end{array}$ & $\begin{array}{c}-0.00374^{* * *} \\
(0.00065)\end{array}$ & $\begin{array}{c}-0.00389 * * * \\
(0.00075)\end{array}$ \\
\hline No. of Board Meeting & $\begin{array}{c}0.00011 * * * \\
(0.00003)\end{array}$ & $\begin{array}{c}0.00011 * * * \\
(0.00003)\end{array}$ & $\begin{array}{c}0.00012^{* * *} \\
(0.00003)\end{array}$ & $\begin{array}{c}0.00007^{* *} \\
(0.00003)\end{array}$ \\
\hline ROE & $\begin{array}{c}-0.00142 * \\
(0.00078)\end{array}$ & $\begin{array}{c}-0.00159 * * \\
(0.00079)\end{array}$ & $\begin{array}{c}-0.00159 * * \\
(0.00079)\end{array}$ & $\begin{array}{c}-0.00166^{*} \\
(0.00085)\end{array}$ \\
\hline Firm Age & $\begin{array}{c}0.00005^{* *} \\
(0.00002)\end{array}$ & $\begin{array}{c}0.00005^{* *} \\
(0.00002)\end{array}$ & $\begin{array}{c}0.00005^{* *} \\
(0.00002)\end{array}$ & $\begin{array}{c}0.00006 * * \\
(0.00002)\end{array}$ \\
\hline Independent Director Ratio & $\begin{array}{c}0.00253 \\
(0.00212)\end{array}$ & $\begin{array}{c}0.00255 \\
(0.00213)\end{array}$ & $\begin{array}{c}0.00252 \\
(0.00215)\end{array}$ & $\begin{array}{c}0.00357 \\
(0.00238)\end{array}$ \\
\hline Size & $\begin{array}{l}-0.00014 \\
(0.00013)\end{array}$ & $\begin{array}{l}-0.00012 \\
(0.00014)\end{array}$ & $\begin{array}{l}-0.00013 \\
(0.00014)\end{array}$ & $\begin{array}{c}0.00003 \\
(0.00014)\end{array}$ \\
\hline Institutional_Shareholding & $\begin{array}{c}0.00005^{* *} \\
(0.00002)\end{array}$ & $\begin{array}{c}0.00005^{* *} \\
(0.00002)\end{array}$ & $\begin{array}{l}0.00005^{* *} \\
(0.00002)\end{array}$ & $\begin{array}{c}0.00003 \\
(0.00002)\end{array}$ \\
\hline Board Size & $\begin{array}{l}-0.00012 \\
(0.00008)\end{array}$ & $\begin{array}{l}-0.00012 \\
(0.00008)\end{array}$ & $\begin{array}{l}-0.00012 \\
(0.00008)\end{array}$ & $\begin{array}{l}-0.00012 \\
(0.00009)\end{array}$ \\
\hline Is_Chairman_Family & $\begin{array}{c}-0.00040 * \\
(0.00022)\end{array}$ & $\begin{array}{l}-0.00023 \\
(0.00022)\end{array}$ & $\begin{array}{l}-0.00037 \\
(0.00023)\end{array}$ & $\begin{array}{l}-0.00023 \\
(0.00023)\end{array}$ \\
\hline CEO_Tenure & $\begin{array}{l}-0.00003 \\
(0.00003)\end{array}$ & $\begin{array}{l}-0.00002 \\
(0.00003)\end{array}$ & $\begin{array}{l}-0.00002 \\
(0.00003)\end{array}$ & $\begin{array}{l}-0.00001 \\
(0.00003)\end{array}$ \\
\hline CEO Pay & $\begin{array}{c}0.00065^{* * *} \\
(0.00018)\end{array}$ & $\begin{array}{c}0.00062^{* * *} \\
(0.00018)\end{array}$ & $\begin{array}{c}0.00063^{* * *} \\
(0.00018)\end{array}$ & $\begin{array}{c}0.00046 * * \\
(0.00020)\end{array}$ \\
\hline CEO Power & $\begin{array}{l}-0.00145 \\
(0.00117)\end{array}$ & $\begin{array}{l}-0.00104 \\
(0.00120)\end{array}$ & $\begin{array}{l}-0.00084 \\
(0.00120)\end{array}$ & $\begin{array}{c}-0.00254^{*} \\
(0.00132)\end{array}$ \\
\hline Constant & $\begin{array}{l}-0.00425 \\
(0.0026 I)\end{array}$ & $\begin{array}{c}-0.00509 * \\
(0.00269)\end{array}$ & $\begin{array}{c}-0.00484 * \\
(0.00269)\end{array}$ & $\begin{array}{c}-0.00533^{*} \\
(0.00299)\end{array}$ \\
\hline Year & Yes & Yes & Yes & Yes \\
\hline $\begin{array}{l}\text { Industry } \\
\text { R-squared }\end{array}$ & $\begin{array}{c}\text { Yes } \\
0.120\end{array}$ & $\begin{array}{c}\text { Yes } \\
0.120\end{array}$ & $\begin{array}{c}\text { Yes } \\
0.118\end{array}$ & $\begin{array}{c}\text { Yes } \\
0.085\end{array}$ \\
\hline
\end{tabular}

Notes: Robust standard errors are in parenthesis. *Shows significance level. ***, $* *$, and *Indicates $P<1 \%, 5 \%$, and $10 \%$. 
Table 7 Regression Outcomes with R\&D Assets

\begin{tabular}{|c|c|c|c|}
\hline \multirow[t]{2}{*}{ Variables } & MI2 & MI3 & MI4 \\
\hline & $\mathbf{R} \& \mathbf{D}$ & R\&D & R\&D \\
\hline Family CEO \& Controller & $\begin{array}{c}0.00102^{* * * *} \\
(0.00035)\end{array}$ & & \\
\hline Family CEO \& Non-controller & & $\begin{array}{c}-0.00138 * * * \\
(0.00053)\end{array}$ & \\
\hline Non-family CEO & & & $\begin{array}{c}-0.00064 * \\
(0.00034)\end{array}$ \\
\hline CEO Overconfidence & $\begin{array}{c}0.00044 \\
(0.00030)\end{array}$ & $\begin{array}{l}-0.00008 \\
(0.00025)\end{array}$ & $\begin{array}{c}-0.00123^{* * * *} \\
(0.00034)\end{array}$ \\
\hline Family CEO \& Controller X CEO Overconfidence & $\begin{array}{c}-0.00167 * * * \\
(0.00049)\end{array}$ & & \\
\hline Family CEO \& Non-controller X CEO Overconfidence & & $\begin{array}{c}0.00011 \\
(0.00058)\end{array}$ & \\
\hline Non-family CEO X CEO Overconfidence & & & $\begin{array}{c}0.00181 * * * \\
(0.00047)\end{array}$ \\
\hline Leverage & $\begin{array}{c}-0.00385 * * * \\
(0.00075)\end{array}$ & $\begin{array}{c}-0.00417 * * * \\
(0.00070)\end{array}$ & $\begin{array}{c}-0.00389 * * * \\
(0.00075)\end{array}$ \\
\hline $\begin{array}{l}\text { No. of Board Meeting } \\
\text { ROE }\end{array}$ & $\begin{array}{c}0.00007^{*} \\
(0.00003) \\
-0.00158^{*} \\
(0.00085)\end{array}$ & $\begin{array}{c}0.00012^{* * *} \\
(0.00003) \\
-0.0015 I^{* *} \\
(0.00076)\end{array}$ & $\begin{array}{c}0.00007^{* *} \\
(0.00003) \\
-0.00167^{*} \\
(0.00085)\end{array}$ \\
\hline Firm Age & $\begin{array}{l}0.00007^{* *} \\
(0.00002)\end{array}$ & $\begin{array}{l}0.00006 * * \\
(0.00002)\end{array}$ & $\begin{array}{l}0.00006 * * \\
(0.00002)\end{array}$ \\
\hline $\begin{array}{l}\text { Independent Director Ratio } \\
\text { Size }\end{array}$ & $\begin{array}{c}0.00263 \\
(0.00243) \\
0.00006 \\
(0.00014)\end{array}$ & $\begin{array}{c}0.00294 \\
(0.00218) \\
-0.00003 \\
(0.00014)\end{array}$ & $\begin{array}{c}0.00273 \\
(0.00244) \\
0.00005 \\
(0.00014)\end{array}$ \\
\hline Institutional_Shareholding & $\begin{array}{c}0.00003 \\
(0.00002)\end{array}$ & $\begin{array}{c}0.00006^{* * * *} \\
(0.00002)\end{array}$ & $\begin{array}{c}0.00003 \\
(0.00002)\end{array}$ \\
\hline Board Size & $\begin{array}{l}-0.00014 \\
(0.00009)\end{array}$ & $\begin{array}{l}-0.00010 \\
(0.00008)\end{array}$ & $\begin{array}{l}-0.00015 \\
(0.00009)\end{array}$ \\
\hline Is_Chairman_Family & $\begin{array}{l}-0.00030 \\
(0.00024)\end{array}$ & $\begin{array}{l}-0.00000 \\
(0.00021)\end{array}$ & $\begin{array}{l}-0.00019 \\
(0.00025)\end{array}$ \\
\hline CEO_Tenure & $\begin{array}{l}-0.00003 \\
(0.00003)\end{array}$ & $\begin{array}{c}0.00001 \\
(0.00003)\end{array}$ & $\begin{array}{l}-0.00002 \\
(0.00003)\end{array}$ \\
\hline CEO Pay & $\begin{array}{l}0.00047^{* *} \\
(0.00020)\end{array}$ & $\begin{array}{c}0.00056^{* * * *} \\
(0.00018)\end{array}$ & $\begin{array}{l}0.00045 * * \\
(0.00020)\end{array}$ \\
\hline CEO Power & $\begin{array}{c}-0.00262^{* *} \\
(0.00132)\end{array}$ & $\begin{array}{l}-0.00117 \\
(0.00128)\end{array}$ & $\begin{array}{c}-0.00258^{*} \\
(0.00132)\end{array}$ \\
\hline Constant & $\begin{array}{c}-0.00553 * \\
(0.00302)\end{array}$ & $\begin{array}{c}-0.00606 * * \\
(0.00269)\end{array}$ & $\begin{array}{l}-0.00459 \\
(0.00304)\end{array}$ \\
\hline
\end{tabular}

(Continued) 
Table 7 (Continued).

\begin{tabular}{|l|c|c|c|}
\hline \multirow{2}{*}{ Variables } & MI2 & MI3 & MI4 \\
\cline { 2 - 4 } & R\&D & R\&D & R\&D \\
\hline Year & Yes & Yes & Yes \\
Industry & Yes & Yes & 0.119 \\
R-squared & 0.090 & 090 \\
\hline
\end{tabular}

Notes: Robust standard errors are in parenthesis. *Shows significance level. ***, **, and *Indicates $P<1 \%, 5 \%$, and $10 \%$.

fluctuation in earnings. However, some firms just used descriptive statements, for instance, "may substantially increase."

As mentioned above, this study classifies top managers as overconfident if the frequency of over-forecast periods (ie, forecast income ends up being higher than actual incomes) is higher than that of the under-forecast during the sample phase.

The following samples are removed to prevent calculation errors: (1) given the possibility that some firms may exhibit overestimated incomes with a view of obtaining external finance approval, such as bank loans, rather than the possibility of the overconfidence of top managers. The study follows Lin, $\mathrm{Hu}$ and $\mathrm{Chen}^{75}$ and eliminated seven sample companies receiving external funding from earnings prediction announcement within one year. (2) This study deleted 19 sample companies whose board members or CEOs have been replaced during the study sample period to remove the impact of top executive turnovers on a business's earnings forecast. These sample changes often minimize the probability of private information being captured by the earnings forecast.

\section{R\&D Investment}

This study used R\&D investment as a dependent variable, which was measured by yearly $R \& D$ expenditure divided by total sales at the end of the year. This measure of $R \& D$ intensity has been used by several former studies, such as Chen and Diéguez-Soto et al's studies. ${ }^{78,79}$ In addition, this study used another measure of $R \& D$ investment by calculating the ratio of $R \& D$ expenditure and total assets at the end of the year. ${ }^{80,81}$ The other measure of $R \& D$ investment was used to verify the robustness of our results.

This study also used several control variables to manage firms' specific characteristics. The empirical literature discussed the effects of control variables on R\&D investment intensity. ${ }^{63,82}$ Accordingly, this study used leverage as a control variable and measured it as total debt scaled by total assets. We also empirically investigated the effect of governance variables on R\&D investment; therefore, we incorporated the ratio of independent directors as a governance variable, which is measured as the total board size divided by independent directors in the board. Moreover, the total number of board meetings of the board in a specific year is considered. We also included "the chairman is a family member" as a dummy variable. The age of the firm is also included as a control variable. ${ }^{63}$ The common component of the annual book performance report is the return on equity, which also plays a role to control the firm-specific characteristics. Additionally, the size of the firm is part of our control variables, and institutional shareholding was used as a control variable. The study further includes the tenure CEO, CEO pay measured as total remuneration received by a $\mathrm{CEO}$ in a year, and CEO power measured as CEO pay divided by the sum of the pay of top five senior executives.

\section{Empirical Model}

$$
\begin{aligned}
R D_{i, t} & =\alpha_{o}+\alpha_{1} \text { CEOS type }_{i, t} \\
& +\alpha_{2}{\text { CEOS } \text { overconfidence }_{i, t}} \\
& +\alpha_{3} \text { CEOs type }_{i, t} *{\text { CEOS } \text { overconfidence }_{i, t}} \\
& +\alpha_{j} \text { CEontrols }_{i, t}+\varepsilon_{i, t}
\end{aligned}
$$

\section{Results}

\section{Mean Comparison}

The difference of means test is run for three types of family CEOs, and Table 1 reports the t-statistics value. All the variables are statistically significant according to the t-statistics values of non-family and family CEOs with actual control right. In the third type of family CEOs, family CEOs and non-controller are statistically significant variables, except for leverage and ROE. 
Table 8 Regression Outcomes with Tobit Model

\begin{tabular}{|c|c|c|c|c|}
\hline \multirow[t]{2}{*}{ Variables } & MI5 & MI6 & MI7 & MI8 \\
\hline & R\&D & R\&D & R\&D & R\&D \\
\hline Family CEO \& Controller & $\begin{array}{l}0.00423 * * \\
(0.00215)\end{array}$ & & & \\
\hline Family CEO \& Non-controller & & $\begin{array}{l}-0.00219 \\
(0.00429)\end{array}$ & & \\
\hline Non-family CEO & & & $\begin{array}{c}-0.00363^{*} \\
(0.00212)\end{array}$ & \\
\hline CEO Overconfidence & & & & $\begin{array}{c}0.00466 * * \\
(0.00230)\end{array}$ \\
\hline Leverage & $\begin{array}{c}-0.03850 * * * \\
(0.00589)\end{array}$ & $\begin{array}{c}-0.03860 * * * \\
(0.00608)\end{array}$ & $\begin{array}{c}-0.03850 \text { **** } \\
(0.00589)\end{array}$ & $\begin{array}{c}-0.04620 * * * \\
(0.00688)\end{array}$ \\
\hline No. of Board Meeting & $\begin{array}{c}0.00152 * * * \\
(0.00027)\end{array}$ & $\begin{array}{c}0.0015 I^{* * * *} \\
(0.00028)\end{array}$ & $\begin{array}{c}0.00155^{* * *} \\
(0.00027)\end{array}$ & $\begin{array}{c}0.00072 * * \\
(0.00031)\end{array}$ \\
\hline ROE & $\begin{array}{c}-0.03170^{* * * *} \\
(0.01020)\end{array}$ & $\begin{array}{c}-0.02770 * * * * \\
(0.01020)\end{array}$ & $\begin{array}{c}-0.03180^{* * * *} \\
(0.01020)\end{array}$ & $\begin{array}{c}-0.02910^{* * * *} \\
(0.01110)\end{array}$ \\
\hline Firm Age & $\begin{array}{c}0.00125^{* * *} \\
(0.00022)\end{array}$ & $\begin{array}{c}0.00109 * * * \\
(0.00022)\end{array}$ & $\begin{array}{c}0.00122^{* * *} \\
(0.00022)\end{array}$ & $\begin{array}{c}0.00104 * * * \\
(0.00025)\end{array}$ \\
\hline Independent Director Ratio & $\begin{array}{c}0.00395 \\
(0.02170)\end{array}$ & $\begin{array}{c}0.02580 \\
(0.02180)\end{array}$ & $\begin{array}{c}0.00438 \\
(0.02170)\end{array}$ & $\begin{array}{c}0.02120 \\
(0.02510)\end{array}$ \\
\hline Size & $\begin{array}{l}0.0027 \text { I** } \\
(0.00132)\end{array}$ & $\begin{array}{l}0.0024 I * \\
(0.00135)\end{array}$ & $\begin{array}{c}0.00263^{* *} \\
(0.00132)\end{array}$ & $\begin{array}{c}0.00428 * * * \\
(0.00153)\end{array}$ \\
\hline Institutional_Shareholding & $\begin{array}{c}0.00048 * * * \\
(0.00017)\end{array}$ & $\begin{array}{l}0.00040 * * \\
(0.00018)\end{array}$ & $\begin{array}{c}0.00049 * * * \\
(0.00017)\end{array}$ & $\begin{array}{c}0.00004 \\
(0.00020)\end{array}$ \\
\hline Board Size & $\begin{array}{c}-0.00132 * \\
(0.00077)\end{array}$ & $\begin{array}{l}-0.00069 \\
(0.00077)\end{array}$ & $\begin{array}{c}-0.00132 * \\
(0.00077)\end{array}$ & $\begin{array}{c}-0.00163^{*} \\
(0.00088)\end{array}$ \\
\hline Is_Chairman_Family & $\begin{array}{c}-0.0070 I^{* * * *} \\
(0.00219)\end{array}$ & $\begin{array}{c}-0.00644 * * * \\
(0.00224)\end{array}$ & $\begin{array}{c}-0.0072 I^{* * * *} \\
(0.00222)\end{array}$ & $\begin{array}{c}-0.007 \mid 8^{* * *} \\
(0.00240)\end{array}$ \\
\hline CEO_Tenure & $\begin{array}{l}-0.00040 \\
(0.00031)\end{array}$ & $\begin{array}{l}-0.00024 \\
(0.00031)\end{array}$ & $\begin{array}{l}-0.00039 \\
(0.00031)\end{array}$ & $\begin{array}{l}-0.00004 \\
(0.00035)\end{array}$ \\
\hline CEO Pay & $\begin{array}{l}-0.00003 \\
(0.00165)\end{array}$ & $\begin{array}{l}-0.00055 \\
(0.00166)\end{array}$ & $\begin{array}{l}-0.00001 \\
(0.00165)\end{array}$ & $\begin{array}{l}-0.00186 \\
(0.00187)\end{array}$ \\
\hline CEO Power & $\begin{array}{l}-0.00100 \\
(0.01210)\end{array}$ & $\begin{array}{c}0.00203 \\
(0.01240)\end{array}$ & $\begin{array}{l}-0.00039 \\
(0.01210)\end{array}$ & $\begin{array}{l}-0.00824 \\
(0.01410)\end{array}$ \\
\hline Constant & $\begin{array}{c}-0.04710 * \\
(0.02840)\end{array}$ & $\begin{array}{c}-0.04820 * \\
(0.02920)\end{array}$ & $\begin{array}{l}-0.04240 \\
(0.02830)\end{array}$ & $\begin{array}{l}-0.04370 \\
(0.03290)\end{array}$ \\
\hline $\begin{array}{l}\text { Year } \\
\text { Industry }\end{array}$ & $\begin{array}{l}\text { Yes } \\
\text { Yes }\end{array}$ & $\begin{array}{l}\text { Yes } \\
\text { Yes }\end{array}$ & $\begin{array}{l}\text { Yes } \\
\text { Yes }\end{array}$ & $\begin{array}{l}\text { Yes } \\
\text { Yes }\end{array}$ \\
\hline
\end{tabular}

Notes: Robust standard errors are in parenthesis. *Shows significance level. ***, **, and *Indicates $\mathrm{P}<1 \%, 5 \%$, and $10 \%$. 
Table 9 Regression Outcomes with Tobit Model

\begin{tabular}{|c|c|c|c|}
\hline \multirow[t]{2}{*}{ Variables } & MI9 & M20 & M2I \\
\hline & R\&D & $\mathbf{R} \& \mathbf{D}$ & R\&D \\
\hline Family CEO \& Controller & $\begin{array}{c}0.00793 * * * \\
(0.00302)\end{array}$ & & \\
\hline Family CEO \& Non-controller & & $\begin{array}{l}-0.00265 \\
(0.00636)\end{array}$ & \\
\hline Non-family CEO & & & $\begin{array}{c}-0.007 \mid 2^{* *} \\
(0.00300)\end{array}$ \\
\hline CEO Overconfidence & $\begin{array}{c}0.00990 * * * \\
(0.00268)\end{array}$ & $\begin{array}{l}0.00456 * \\
(0.00236)\end{array}$ & $\begin{array}{l}-0.00606 \\
(0.00385)\end{array}$ \\
\hline Family CEO \& controller X CEO Overconfidence & $\begin{array}{c}-0.01840 * * * \\
(0.00494)\end{array}$ & & \\
\hline $\begin{array}{l}\text { Family CEO \& non-controller X CEO Overconfidence } \\
\text { Non-family CEO X CEO Overconfidence }\end{array}$ & & $\begin{array}{c}0.00237 \\
(0.00947)\end{array}$ & $\begin{array}{c}0.01630 * * * \\
(0.00470)\end{array}$ \\
\hline Leverage & $\begin{array}{c}-0.04550 * * * \\
(0.00686)\end{array}$ & $\begin{array}{c}-0.04610^{* * * *} \\
(0.00688)\end{array}$ & $\begin{array}{c}-0.04580 \text { **** } \\
(0.00686)\end{array}$ \\
\hline No. of Board Meeting & $\begin{array}{l}0.00069 * * \\
(0.00031)\end{array}$ & $\begin{array}{l}0.00072 * * \\
(0.00032)\end{array}$ & $\begin{array}{c}0.00067 * * \\
(0.00031)\end{array}$ \\
\hline ROE & $\begin{array}{c}-0.02870^{* * *} \\
(0.01110)\end{array}$ & $\begin{array}{c}-0.02900 * * * \\
(0.01110)\end{array}$ & $\begin{array}{c}-0.02920 * * * \\
(0.01110)\end{array}$ \\
\hline Firm Age & $\begin{array}{c}0.00107^{* * *} \\
(0.00025)\end{array}$ & $\begin{array}{c}0.00104^{* * *} \\
(0.00025)\end{array}$ & $\begin{array}{c}0.00110 * * * \\
(0.00025)\end{array}$ \\
\hline Independent Director Ratio & $\begin{array}{c}0.01340 \\
(0.02510)\end{array}$ & $\begin{array}{c}0.02130 \\
(0.02510)\end{array}$ & $\begin{array}{c}0.01220 \\
(0.02520)\end{array}$ \\
\hline Size & $\begin{array}{c}0.00433 * * * \\
(0.00153)\end{array}$ & $\begin{array}{c}0.00425^{* * *} \\
(0.00153)\end{array}$ & $\begin{array}{c}0.00452^{* * * *} \\
(0.00153)\end{array}$ \\
\hline Institutional_Shareholding & $\begin{array}{c}0.00002 \\
(0.00020)\end{array}$ & $\begin{array}{c}0.00004 \\
(0.00020)\end{array}$ & $\begin{array}{c}0.00003 \\
(0.00020)\end{array}$ \\
\hline Board Size & $\begin{array}{c}-0.00180 * * \\
(0.00088)\end{array}$ & $\begin{array}{c}-0.0016 I^{*} \\
(0.00088)\end{array}$ & $\begin{array}{c}-0.00186 * * \\
(0.00088)\end{array}$ \\
\hline Is_Chairman_Family & $\begin{array}{c}-0.00750 * * * \\
(0.00243)\end{array}$ & $\begin{array}{c}-0.00707^{* * *} \\
(0.00244)\end{array}$ & $\begin{array}{c}-0.00726 * * * \\
(0.00248)\end{array}$ \\
\hline CEO_Tenure & $\begin{array}{l}-0.00022 \\
(0.00036)\end{array}$ & $\begin{array}{l}-0.00004 \\
(0.00035)\end{array}$ & $\begin{array}{l}-0.00021 \\
(0.00036)\end{array}$ \\
\hline CEO Pay & $\begin{array}{l}-0.00178 \\
(0.00186)\end{array}$ & $\begin{array}{l}-0.00184 \\
(0.00187)\end{array}$ & $\begin{array}{l}-0.00196 \\
(0.00186)\end{array}$ \\
\hline CEO Power & $\begin{array}{l}-0.00812 \\
(0.01410)\end{array}$ & $\begin{array}{l}-0.00837 \\
(0.01410)\end{array}$ & $\begin{array}{l}-0.00845 \\
(0.01410)\end{array}$ \\
\hline Constant & $\begin{array}{l}-0.04260 \\
(0.03290)\end{array}$ & $\begin{array}{l}-0.04360 \\
(0.03290)\end{array}$ & $\begin{array}{l}-0.03630 \\
(0.03290)\end{array}$ \\
\hline
\end{tabular}

(Continued) 
Table 9 (Continued).

\begin{tabular}{|l|c|c|c|}
\hline \multirow{2}{*}{ Variables } & M19 & M20 & M2I \\
\cline { 2 - 4 } & R\&D & R\&D & R\&D \\
\hline Year & Yes & Yes & Yes \\
Industry & Yes & Yes & Yes \\
\hline
\end{tabular}

Notes: Robust standard errors are in parenthesis. $*$ Shows significance level. ***, **, and *Indicates $P<1 \%, 5 \%$, and $10 \%$.

\section{Descriptive Analysis}

Table 2 represents the descriptive statistics. From the values, Chinese family firms invest $1.18 \%$ of total sales in R\&D. The non-family CEO's mean value is 0.5330 , which indicates that based on the selective data, $53 \%$ of CEOs do not belong to the family. In the dataset, $40 \%$ of CEOs belonged to the family and are also the actual controller of the family firms. On the contrary, the third type of CEO belongs to the family but is not an actual controller of the family firms. The ratio of the third type of CEO in the dataset is approximately $7 \%$. The dataset mean value of CEO overconfidence is 0.3020 , which means that $30 \%$ of CEOs in our dataset are overconfident. The last column of Table 2 demonstrates the value of variance inflation factors (VIF), where all VIF values are less than 2 , demonstrating the absence of multi-collinearity in the dataset.

\section{Correlation Analysis}

Table 3 shows the outcomes of correlation analysis. The correlation analysis demonstrates that the sample data set is free from multi-collinearity, which is an essential prerequisite of regression analysis. The correlation analysis of our results indicates statistical correlations among the study variables, control variables, and $R \& D$ investment. The dependent variable $R \& D$ investment is negatively correlated with non-family CEO and non-controller family CEO but is positively correlated with family CEOs with actual control rights. Moreover, the results substantiate that CEO overconfidence is positively correlated with $R \& D$ investment.

Table 4 shows the regression outcomes, which indicated that the non-family CEOs show insignificant results but are reluctant to invest in $\mathrm{R} \& \mathrm{D}$ according to the predicted sign. By contrast, family CEOs with full control rights are enthusiastic to invest in risky projects at protracted periods. Hence, HIa is accepted in this case. The third type of CEO, which belongs to the family but without actual control rights, also shows less willingness toward R\&D investment. Hence, H1b is also accepted in this scenario. For the first time, we introduced three types of CEO within Chinese family firms. These three types of CEO statistical results validate different behaviors of CEOs toward R\&D investment. Family CEO and controller have full control rights to make the decisions. In such circumstances, he should have the confidence to take bold decisions, and also, agency conflicts would be at the minimum. The overconfident CEOs have more willingness toward R\&D investment. The positive attitude toward long-term risky projects can cause short-term earnings truncation.

Table 5 demonstrates the instrumental key role of CEO overconfidence among family firm CEOs and R\&D investment. This psychological phenomenon convinces CEOs to take audacious strategic decisions, which ultimately influence organizational outcomes. This study has established some interesting results based on the statistically significant results. The family CEOs with full actual rights behave negatively toward $R \& D$ investment with a moderating role of CEO overconfidence. Hence, $\mathrm{H} 3 \mathrm{a}$ is accepted in this specific case. The family CEO with actual control rights works as a rational CEO and has risk-averse. On the contrary, family CEOs without actual control rights show insignificant results with the moderating role of CEO overconfidence, which is represented by H3b. However, non-family CEOs behave positively toward R\&D investment with the moderating role of CEO overconfidence. Hence, H3c is accepted.

\section{Robustness Check}

We check the robustness of our results and carried out models M1, M2, M3, and M4 from Table 4. This study used to change the $R \& D$ measure as a sale to assets. $R \& D$ investment is measured by total $R \& D$ expenditure divided by total assets. The reported results of the study are partially similar with the significant level and fully parallel 
Table 10 Regression Outcomes with Firm Fixed Effect Model

\begin{tabular}{|c|c|c|c|c|}
\hline \multirow[t]{2}{*}{ Variables } & M22 & M23 & M24 & M25 \\
\hline & R\&D & R\&D & R\&D & R\&D \\
\hline Family CEO \& Controller & $\begin{array}{l}0.00079 * * \\
(0.00069)\end{array}$ & & & \\
\hline Family CEO \& Non-controller & & $\begin{array}{l}-0.00097 \\
(0.00608)\end{array}$ & & \\
\hline Non-family CEO & & & $\begin{array}{l}-0.00148 \\
(0.00314)\end{array}$ & \\
\hline CEO Overconfidence & & & & $\begin{array}{c}0.01230 * * * \\
(0.00422)\end{array}$ \\
\hline Leverage & $\begin{array}{l}-0.00252 \\
(0.00200)\end{array}$ & $\begin{array}{c}-0.01500 * \\
(0.00898)\end{array}$ & $\begin{array}{l}-0.01400 \\
(0.00952)\end{array}$ & $\begin{array}{c}-0.02590 * * \\
(0.01130)\end{array}$ \\
\hline No. of Board Meeting & $\begin{array}{l}-0.00002 \\
(0.00006)\end{array}$ & $\begin{array}{l}0.0007 I^{* *} \\
(0.00029)\end{array}$ & $\begin{array}{c}0.00047 \\
(0.0003 \mathrm{I})\end{array}$ & $\begin{array}{c}0.00047 \\
(0.00037)\end{array}$ \\
\hline ROE & $\begin{array}{l}-0.00130 \\
(0.00220)\end{array}$ & $\begin{array}{l}-0.00325 \\
(0.00956)\end{array}$ & $\begin{array}{l}-0.00208 \\
(0.01030)\end{array}$ & $\begin{array}{l}-0.00222 \\
(0.01170)\end{array}$ \\
\hline Firm Age & $\begin{array}{c}-0.00085^{*} \\
(0.00459)\end{array}$ & $\begin{array}{c}0.00333 \\
(0.02380)\end{array}$ & $\begin{array}{c}0.00769 \\
(0.02420)\end{array}$ & $\begin{array}{c}0.00890 \\
(0.03520)\end{array}$ \\
\hline Independent Director Ratio & $\begin{array}{l}-0.00599 \\
(0.00670)\end{array}$ & $\begin{array}{c}0.04580 \\
(0.02890)\end{array}$ & $\begin{array}{l}0.05240 * \\
(0.03120)\end{array}$ & $\begin{array}{l}-0.01120 \\
(0.03780)\end{array}$ \\
\hline Size & $\begin{array}{l}-0.00017 \\
(0.00051)\end{array}$ & $\begin{array}{l}0.00464 * * \\
(0.00233)\end{array}$ & $\begin{array}{c}0.00830 * * * \\
(0.00247)\end{array}$ & $\begin{array}{c}0.00807^{* * *} \\
(0.00287)\end{array}$ \\
\hline Institutional_Shareholding & $\begin{array}{c}0.00012^{* * *} \\
(0.00004)\end{array}$ & $\begin{array}{c}0.00027 \\
(0.00019)\end{array}$ & $\begin{array}{l}0.00038^{*} \\
(0.0002 I)\end{array}$ & $\begin{array}{c}0.00038 \\
(0.00025)\end{array}$ \\
\hline Board Size & $\begin{array}{c}0.00019 \\
(0.00026)\end{array}$ & $\begin{array}{l}0.00210 * \\
(0.00118)\end{array}$ & $\begin{array}{l}0.00207^{*} \\
(0.00125)\end{array}$ & $\begin{array}{c}0.00133 \\
(0.00153)\end{array}$ \\
\hline Is_Chairman_Family & $\begin{array}{c}-0.00176 * * \\
(0.00070)\end{array}$ & $\begin{array}{l}-0.00290 \\
(0.00312)\end{array}$ & $\begin{array}{c}-0.00973 * * * \\
(0.0033 \mathrm{I})\end{array}$ & $\begin{array}{c}-0.01090 * * * \\
(0.00385)\end{array}$ \\
\hline CEO_Tenure & $\begin{array}{c}0.00024 \\
(0.00015)\end{array}$ & $\begin{array}{l}-0.00014 \\
(0.00069)\end{array}$ & $\begin{array}{l}-0.00018 \\
(0.00073)\end{array}$ & $\begin{array}{l}-0.00024 \\
(0.00084)\end{array}$ \\
\hline CEO Pay & $\begin{array}{c}0.00174^{* * *} \\
(0.00058)\end{array}$ & $\begin{array}{l}-0.00060 \\
(0.00258)\end{array}$ & $\begin{array}{l}-0.00255 \\
(0.00278)\end{array}$ & $\begin{array}{c}-0.00796 * * \\
(0.00335)\end{array}$ \\
\hline CEO Power & $\begin{array}{l}-0.0004 I \\
(0.00298)\end{array}$ & $\begin{array}{l}-0.00766 \\
(0.01210)\end{array}$ & $\begin{array}{c}0.00203 \\
(0.01390)\end{array}$ & $\begin{array}{l}-0.00205 \\
(0.01690)\end{array}$ \\
\hline Constant & $\begin{array}{l}-0.01120 \\
(0.01830)\end{array}$ & $\begin{array}{l}-0.11200 \\
(0.08480)\end{array}$ & $\begin{array}{c}-0.17100^{*} \\
(0.08810)\end{array}$ & $\begin{array}{l}-0.06660 \\
(0.12100)\end{array}$ \\
\hline $\begin{array}{l}\text { Year } \\
\text { Industry } \\
\text { R-squared }\end{array}$ & $\begin{array}{c}\text { Yes } \\
\text { Yes } \\
0.123\end{array}$ & $\begin{array}{c}\text { Yes } \\
\text { Yes } \\
0.122\end{array}$ & $\begin{array}{c}\text { Yes } \\
\text { Yes } \\
0.137\end{array}$ & $\begin{array}{c}\text { Yes } \\
\text { Yes } \\
0.160\end{array}$ \\
\hline
\end{tabular}

Notes: Robust standard errors are in parenthesis. *Shows significance level. ***, **, and *Indicates $P<1 \%, 5 \%$, and $10 \%$. 
Table I I Regression Outcomes with Firm Fixed Effect Model

\begin{tabular}{|c|c|c|c|}
\hline \multirow[t]{2}{*}{ Variables } & M26 & M27 & M28 \\
\hline & R\&D & R\&D & R\&D \\
\hline Family CEO \& Controller & $\begin{array}{c}0.00442 \\
(0.00354)\end{array}$ & & \\
\hline Family CEO \& Non-controller & & $\begin{array}{c}0.00084 \\
(0.00791)\end{array}$ & \\
\hline Non-family CEO & & & $\begin{array}{l}-0.00430 \\
(0.00350)\end{array}$ \\
\hline CEO Overconfidence & $\begin{array}{c}0.01120 * * * \\
(0.00315)\end{array}$ & $\begin{array}{l}0.00698 * * \\
(0.00279)\end{array}$ & $\begin{array}{l}-0.00078 \\
(0.00438)\end{array}$ \\
\hline Family CEO \& Controller X CEO Overconfidence & $\begin{array}{c}-0.01430 * * * \\
(0.00555)\end{array}$ & & \\
\hline Family CEO \& Non-controller X CEO Overconfidence & & $\begin{array}{c}0.00194 \\
(0.01070)\end{array}$ & \\
\hline Non-family CEO X CEO Overconfidence & & & $\begin{array}{l}0.01210 * * \\
(0.00527)\end{array}$ \\
\hline Leverage & $\begin{array}{c}-0.03680 * * * \\
(0.00770)\end{array}$ & $\begin{array}{c}-0.03690 * * * \\
(0.00772)\end{array}$ & $\begin{array}{c}-0.03690 \text { *** } \\
(0.00771)\end{array}$ \\
\hline No. of Board Meeting & $\begin{array}{c}0.00044 \\
(0.0003 \mathrm{I})\end{array}$ & $\begin{array}{c}0.00047 \\
(0.0003 \mathrm{I})\end{array}$ & $\begin{array}{c}0.00043 \\
(0.00031)\end{array}$ \\
\hline ROE & $\begin{array}{l}-0.01320 \\
(0.01010)\end{array}$ & $\begin{array}{l}-0.01330 \\
(0.01010)\end{array}$ & $\begin{array}{l}-0.01340 \\
(0.01010)\end{array}$ \\
\hline $\begin{array}{l}\text { Firm Age } \\
\text { Independent Director Ratio }\end{array}$ & $\begin{array}{c}0.00073 * * \\
(0.00032) \\
0.00394 \\
(0.02780)\end{array}$ & $\begin{array}{c}0.00073^{* *} \\
(0.00032) \\
0.00864 \\
(0.02770)\end{array}$ & $\begin{array}{c}0.00076 * * \\
(0.00032) \\
0.00328 \\
(0.02780)\end{array}$ \\
\hline $\begin{array}{l}\text { Size } \\
\text { Institutional_Shareholding }\end{array}$ & $\begin{array}{c}0.00507^{* * *} \\
(0.00176) \\
0.00021 \\
(0.00020)\end{array}$ & $\begin{array}{c}0.00505^{* * *} \\
(0.00176) \\
0.00021 \\
(0.00020)\end{array}$ & $\begin{array}{c}0.0051 \mathrm{I} * * * \\
(0.00176) \\
0.00021 \\
(0.00020)\end{array}$ \\
\hline Board Size & $\begin{array}{l}-0.00083 \\
(0.00103)\end{array}$ & $\begin{array}{l}-0.00067 \\
(0.00103)\end{array}$ & $\begin{array}{l}-0.00085 \\
(0.00103)\end{array}$ \\
\hline Is_Chairman_Family & $\begin{array}{c}-0.00867 * * * \\
(0.00275)\end{array}$ & $\begin{array}{c}-0.00895 * * * \\
(0.00279)\end{array}$ & $\begin{array}{c}-0.00840 \text { *** } \\
(0.00280)\end{array}$ \\
\hline CEO_Tenure & $\begin{array}{l}-0.00002 \\
(0.00046)\end{array}$ & $\begin{array}{c}0.00005 \\
(0.00046)\end{array}$ & $\begin{array}{l}-0.00001 \\
(0.00046)\end{array}$ \\
\hline CEO Pay & $\begin{array}{l}-0.00235 \\
(0.00217)\end{array}$ & $\begin{array}{l}-0.00245 \\
(0.00218)\end{array}$ & $\begin{array}{l}-0.00244 \\
(0.00217)\end{array}$ \\
\hline CEO Power & $\begin{array}{l}-0.00147 \\
(0.01400)\end{array}$ & $\begin{array}{l}-0.00261 \\
(0.01400)\end{array}$ & $\begin{array}{l}-0.00217 \\
(0.01400)\end{array}$ \\
\hline Constant & $\begin{array}{r}-0.04990 \\
(0.03880)\end{array}$ & $\begin{array}{r}-0.05020 \\
(0.03890)\end{array}$ & $\begin{array}{r}-0.04520 \\
(0.03890)\end{array}$ \\
\hline
\end{tabular}

(Continued) 
Table I I (Continued).

\begin{tabular}{|l|c|c|c|}
\hline Variables & M26 & M27 & M28 \\
\cline { 2 - 4 } & R\&D & R\&D & R\&D \\
\hline Year & Yes & Yes & Yes \\
Industry & Yes & Yes & 0.132 \\
R-squared & 0.141 & 0.128 \\
\hline
\end{tabular}

Notes: Robust standard errors are in parenthesis. *Shows significance level. ***, **, and *Indicates $P<1 \%, 5 \%$, and $10 \%$.

with the predicted sign shown in models M8, M9, M10, and M11 in Table 6. Similarly, this study carried out models M5, M6, and M7 and exhibited the regression outcomes in models M12, M13, and M14 in Table 7. The regression outcomes are fully parallel with respect to the significance level and concerning predicted signs. We again regressed models $\mathrm{M} 1, \mathrm{M} 2, \mathrm{M} 3$, and M4 using the Tobit regression model. We censored our dependent variable R\&D investment by the upper value. The Tobit model is proposed to estimate the linear relationship among variables when either a right or left censoring occurs in the dependent variable. A similar approach was also used by Bozec and Di Vito. ${ }^{83}$

Table 8 presents the output of the Tobit regression model, and our results in models M15, M16, M17, and M18 remained quantitatively similar (partially similar with significant level and fully parallel with predicted sign) to models those in M1, M2, M3, and M4. Similarly, we again regressed models M5, M6, and M7 by the Tobit regression model. Table 9 presents the output of the Tobit regression model, and our results in models M19, M20, and M21 remained quantitatively similar to models M5, M7, and M8.

Table 10 presents the output of the firm fixed effect regression model, and our results in models M22, M23, M24 and M25 remained quantitatively similar (partially similar with significant level and fully parallel with predicted sign) to models M1, M2, M3 and M4. Similarly, we again regressed models M5, M6 and M7 by firm fixed effect regression model. Table 11 presents the output of the firm fixed effect regression model, and our results in models M26, M27 and M28 remained quantitatively similar to models M5, M7 and M8.

\section{Endogeneity}

The generalized method of moments (GMM) is applied for overtime regulation of heteroscedasticity and autoregression pertinent to $\mathrm{R} \& \mathrm{D}$ intensity, whereas lagged value of dependent variable rationalizes the impact of preceding R\&D on subsequent R\&D investment. ${ }^{84}$ To tackle the endogeneity problem, the Arellano and Bond ${ }^{84}$ testing approach is utilized which is in-line with Lim's ${ }^{85}$ study. We investigated in this field to test the prevailing econometric methods: lagging independent variables, OLS model, Tobit model, firm fixed effects mode, control variables, and GMM for dynamic models. After carefully dealing with endogeneity issues, we found strong evidence that the true relationship between CEOs and subsequent R\&D investment. The GMM model results are reported in Table 12 .

\section{Discussion and Conclusion}

This study aims to promote the understanding of this research stream. Categorizing CEOs with regard to the essence of their own nature and diversified control make this study a ground breaking in family firm's literature. From a capability-based perspective, this study examines what specific resources and capabilities emerge when family members assume the position of CEOs and how firm creativity underlies these resources and capabilities. Considering different types of family firm CEOs, this study demonstrates significant differences regarding their attitude toward R\&D spending. Family CEOs possessing full control rights are more prejudiced to invest in $R \& D$ projects, thereby supporting H1a.

The empirical study contributes regarding inside and outside CEOs R\&D investment behavior. This study highlights the inside of CEO's vigorous nature toward R\&D investment subject to the long-term incentives, whereas the attributes from the outside are lacking. To generate loyalty and hope for future internal candidates, family firms rely on inside CEOs, ${ }^{86}$ exploiting insider experience and networks ${ }^{87}$ and mitigating information deformity. ${ }^{88}$ Family firm CEOs embedded with full management privilege develop a long-term outlook because they serve as their company's farsighted stewards, have long tenures, 
Table I 2 Regression Outcome with GMM

\begin{tabular}{|c|c|c|c|c|}
\hline \multirow[t]{2}{*}{ Variables } & M29 & M30 & M3I & M32 \\
\hline & R\&D & R\&D & R\&D & R\&D \\
\hline L. R\&D & $\begin{array}{l}0.248 * * * \\
(0.0915)\end{array}$ & $\begin{array}{l}0.248 * * * \\
(0.0914)\end{array}$ & $\begin{array}{l}0.248 * * * \\
(0.0915)\end{array}$ & $\begin{array}{l}-0.0942 \\
(0.0898)\end{array}$ \\
\hline Family CEO \& Controller & $\begin{array}{c}0.0488 * * \\
(0.0295)\end{array}$ & & & \\
\hline Family CEO \& Non-controller & & $\begin{array}{c}-0.0194 * \\
(0.0501)\end{array}$ & & \\
\hline Non-family CEO & & & $\begin{array}{c}-0.0430 * \\
(0.0261)\end{array}$ & \\
\hline CEO Overconfidence & & & & $\begin{array}{l}0.0129 * * \\
(0.00663)\end{array}$ \\
\hline Leverage & $\begin{array}{c}-0.0688 \\
(0.120)\end{array}$ & $\begin{array}{c}-0.0646 \\
(0.119)\end{array}$ & $\begin{array}{c}-0.0687 \\
(0.120)\end{array}$ & $\begin{array}{c}-0.0386 * * \\
(0.0197)\end{array}$ \\
\hline No. of Board Meeting & $\begin{array}{l}0.00707 \\
(0.0130)\end{array}$ & $\begin{array}{l}0.00709 \\
(0.0130)\end{array}$ & $\begin{array}{l}0.00708 \\
(0.0130)\end{array}$ & $\begin{array}{l}0.000596 * \\
(0.000317)\end{array}$ \\
\hline ROE & $\begin{array}{l}-0.372 \\
(0.57 I)\end{array}$ & $\begin{array}{l}-0.383 \\
(0.57 I)\end{array}$ & $\begin{array}{l}-0.37 \mathrm{I} \\
(0.570)\end{array}$ & $\begin{array}{c}-0.00710 \\
(0.0107)\end{array}$ \\
\hline Firm Age & $\begin{array}{c}0.0721 \\
(0.0470)\end{array}$ & $\begin{array}{c}0.0599 \\
(0.0457)\end{array}$ & $\begin{array}{c}0.0726 \\
(0.047 I)\end{array}$ & $\begin{array}{c}-0.000154 \\
(0.00175)\end{array}$ \\
\hline Independent Director Ratio & $\begin{array}{l}0.0936 \\
(0.334)\end{array}$ & $\begin{array}{c}0.101 \\
(0.335)\end{array}$ & $\begin{array}{l}0.0943 \\
(0.334)\end{array}$ & $\begin{array}{c}0.041 \mathrm{I} \\
(0.0687)\end{array}$ \\
\hline Size & $\begin{array}{r}-0.0484 \\
(0.0876)\end{array}$ & $\begin{array}{l}-0.0369 \\
(0.0869)\end{array}$ & $\begin{array}{l}-0.0471 \\
(0.0874)\end{array}$ & $\begin{array}{c}0.0124 \\
(0.00779)\end{array}$ \\
\hline $\begin{array}{l}\text { Institutional_Shareholding } \\
\text { Board Size }\end{array}$ & $\begin{array}{c}0.0144 \\
(0.0205) \\
0.00727 \\
(0.0162)\end{array}$ & $\begin{array}{c}0.0145 \\
(0.0206) \\
0.00621 \\
(0.0162)\end{array}$ & $\begin{array}{c}0.0144 \\
(0.0205) \\
0.00738 \\
(0.0161)\end{array}$ & $\begin{array}{c}0.000503 \\
(0.0004 I 8) \\
0.00549 \\
(0.00436)\end{array}$ \\
\hline Is_Chairman_Family & $\begin{array}{c}0.0128 \\
(0.0372)\end{array}$ & $\begin{array}{c}0.0175 \\
(0.0410)\end{array}$ & $\begin{array}{l}0.00951 \\
(0.0370)\end{array}$ & $\begin{array}{r}-0.00894 \\
(0.00844)\end{array}$ \\
\hline $\begin{array}{l}\text { CEO_Tenure } \\
\text { CEO Pay }\end{array}$ & $\begin{array}{c}0.0137^{*} \\
(0.00797) \\
-0.256 \\
(0.251)\end{array}$ & $\begin{array}{c}0.0135^{*} \\
(0.00823) \\
-0.248 \\
(0.250)\end{array}$ & $\begin{array}{c}0.0139 * \\
(0.00818) \\
-0.268 \\
(0.260)\end{array}$ & $\begin{array}{l}0.000712 \\
(0.00118) \\
0.00921 * * \\
(0.004 I 3)\end{array}$ \\
\hline CEO Power & $\begin{array}{l}-1.115 \\
(0.950)\end{array}$ & $\begin{array}{l}-1.095 \\
(0.943)\end{array}$ & $\begin{array}{l}-1.118 \\
(0.952)\end{array}$ & $\begin{array}{c}-0.00875 \\
(0.0129)\end{array}$ \\
\hline $\begin{array}{l}\text { Constant } \\
\text { Observations } \\
\text { Number of code }\end{array}$ & $\begin{array}{c}3.852 \\
(3.658) \\
1856 \\
702\end{array}$ & $\begin{array}{c}3.610 \\
(3.650) \\
1856 \\
702\end{array}$ & $\begin{array}{c}4.018 \\
(3.759) \\
1856 \\
702\end{array}$ & $\begin{array}{c}-0.424^{* *} \\
(0.194) \\
1301 \\
489\end{array}$ \\
\hline
\end{tabular}

Notes: Robust standard errors are in parenthesis. *Shows significance level. ***, **, and *Indicates $P<1 \%, 5 \%$, and $10 \%$. 
and are less likely to be penalized for their abysmal performance.

Thus, family CEOs without actual control rights and non-family CEOs have similar behavior regarding their lack of intentions to invest in $\mathrm{R} \& \mathrm{D}$ projects as compared to family CEOs with actual control rights. Agency issues arise in the absence of actual control rights. Moreover, such constraints retard their intentions to invest in R\&D projects as compared to the family CEOs with actual control rights. This result is coherent with SEW viewpoint; a family CEO will display the desire of the family to retain emotional endowment. ${ }^{89}$

Although CEOs are a sovereign body, in absence of actual control rights, the top management acts as the decision-making body. Hence, the absence of actual control rights hampers CEOs' abilities toward R\&D investment leading their behavior to negatively affect subsequent family firm $R \& D$ investment decisions. $R \& D$ investments need a long-term outlook because they are extremely unpredictable, involve substantial sums of risk, and have long horizons of payoff. The short-term attention of non-family CEOs (H1c), however, makes them unwilling to invest in R\&D over ventures that yield rapid outcomes. However, results from an investment may have adverse effects on their financial resources and current employment. A nonfamily CEO is arguably the most significant non-family figure a family firm can employ. Given the small pool of family members, family firms routinely employ such individuals; however, our understanding is not intact. ${ }^{90}$

H2 upholds the overconfident CEOs' behavior to invest more in R\&D projects as compared to rational CEOs. Thus, we can conclude that overconfident CEOs are more passionate about risky, skilled, and vision-sensitive companies. Overconfident CEOs can also actively seek creativity because of the low anticipated payoff. ${ }^{71}$ On the contrary, rational managers in terms of stakeholders prefer to invest in $R \& D$ projects yielding perpetual outcomes and innovative instead of risky projects with uncertain outcomes. Overconfident CEOs psychologically edge to invest in more risky but potentially suitable projects that will lead them with good outcomes. Moreover, they have an edge to conceal low earnings to show the good reputation of the firm. ${ }^{91}$ In the short run, R\&D investment increases the firm expenditure, consequently, causing the reported earnings of risky low-earning projects to decline. Overconfident CEOs also underweight the earning shortfall due to an increase in $R \& D$ expenditure at the cost of expected returns from such investments. Such risky long-term investment decisions made by the overconfident CEOs yielding substantial outcomes cause to increase firm value.

This study paradoxically identified the psychological impact of overconfident CEOs and sensible CEOs. Several studies found that people with control rights are susceptible to overconfidence. Hence, considerable researchers confirmed the widespread existence of overconfidence behavior, and most studies focused on potential explanations. ${ }^{71}$ The present study identifies that family CEO with actual control rights will tend to avoid investing in riskier R\&D projects in the case of CEO overconfidence as a moderating factor ( $\mathrm{H} 3 \mathrm{a})$. The literature also supported that an overconfident family CEO having actual control right becomes risk-averse in nature and favors to take rational decision by making underinvestment in risky projects rather than risky investments. ${ }^{56}$ The attribute of complete control right connects family CEOs with SEW. The CEO's stake induces him to avoid investing in riskier projects. With a moderating function of overconfidence, this study establishes that the family CEO invests in shortterm $R \& D$ projects and cares for minority stakeholders, and safeguard family wealth. However, our results for CEO overconfidence as a moderating factor for family CEOs without actual control right and $\mathrm{R} \& \mathrm{D}$ reveals insignificant outcomes.

CEO overconfidence as a moderating factor acts positively between non-family CEOs and R\&D investment. An overconfident CEO assumes that the market value for riskfree debt funding is correct in this case. However, this result disagrees with the potential new shareholders on the value of an equity interest in the company and hence on the relevant price of newly distributed shares. Overconfident CEOs remain reluctant to use external funding and issue limited equity. ${ }^{92}$ A higher stock return volatility is observed for the firms having overconfident CEOs, which is consistent with their acquisition of riskier projects. Family firms patent and citation count data verify the overconfident CEOs' overinvestment in R\&D projects. ${ }^{71}$ Some studies suggested the positive impact of overconfidence behavior of CEOs on decision implementation, ${ }^{93}$ stimulating agents to make a risky decision in lieu of principal, ${ }^{56,94}$ or combating information externality issues via organizational and experimentation stimulation. ${ }^{95}$ However, non-family CEOs heading family firms show greater investment tendency toward $\mathrm{R} \& \mathrm{D}$ and $\mathrm{M} \& \mathrm{~A}$ investment activities, suggesting a unique investment horizon perception of risk. ${ }^{96}$ 


\section{Limitations and Future Recommendations}

This work has few limitations that offer future research opportunities. This study has focused on Chinese family firms only, and it is important to include the cross-cultural study of our proposed model. We did not obtain actual percentages of the CEOs ownership.

\section{Managerial Summary}

This article helps to explain why "firms managed by family chief executive officers (CEOs) behave differently from those managed by non-family or overconfident CEOs." On the one hand, family CEOs with full control rights offer advantages to firms in the long-run perspective and enhance the R\&D productivity. On the other hand, family CEOs without control rights and nonfamily CEOs are risk-averse and consistent with the behavioral agency model (BAM). We investigate the mysterious outcome of weaker creativity (family CEOs without actual control rights). However, the result shows that R\&D productivity was reduced, which contradicts BAM. The findings of this study are still under the hypothesized assumption-a firm's R\&D output increases when CEOs are overconfident, except for family CEOs having full control rights. However, we do not advocate hiring overconfident or non-family CEOs; instead, we suggest R\&D firms count technological areas of expertise during CEO recruitment. Investors also seem to be unfamiliar with overconfidence in CEOs today. In view of the statements and behavior of family firm CEOs, this study will benefit company stakeholders, including staff, customers, suppliers, and clients. This study would also help board members make the right choices and make sensible decisions about retaining family CEOs (with or without actual control rights) or hiring non-family CEOs.

\section{Data Statement}

The data that support the findings of this analytical study are obtained from CSMAR, a reliable database (https://us. gtadata.com/). CSMAR is an open access database for listed institutions.

\section{Ethics Approval}

Institutional review board (IRB) approval for this study is not required under the condition that this chapter does not contain any studies with human participants performed by any of the authors.

\section{Disclosure}

The authors report no conflicts of interest in this work.

\section{References}

1. Sitthipongpanich T, Polsiri P. Do CEO and board characteristics matter? A study of Thai family firms. J Fam Bus Strategy. 2015;6 (2):119-129. doi:10.1016/j.jfbs.2015.01.002

2. Faccio M, Lang LH. The ultimate ownership of Western European corporations. J Financ Econ. 2002;65(3):365-395. doi:10.1016/ S0304-405X(02)00146-0

3. Anderson RC, Reeb DM. Founding-family ownership and firm performance: evidence from the S\&P 500. J Finance. 2003;58 (3):1301-1328. doi:10.1111/1540-6261.00567

4. Dieleman M. Reaping what you sow: the family firm innovation trajectory. J Fam Bus Strategy. 2018.

5. De Massis A, Frattini F, Lichtenthaler U. Research on technological innovation in family firms: present debates and future directions. Fam Bus Rev. 2013;26(1):10-31. doi:10.1177/0894486512466258

6. Chen H-L, Hsu W-T. Family ownership, board independence, and R\&D investment. Fam Bus Rev. 2009;22(4):347-362. doi:10.1177/ 0894486509341062

7. Munari F, Oriani R, Sobrero M. The effects of owner identity and external governance systems on R\&D investments: a study of Western European firms. Res Policy. 2010;39(8):1093-1104. doi:10.1016/j.respol.2010.05.004

8. Chrisman JJ, Patel PC. Variations in R\&D investments of family and nonfamily firms: behavioral agency and myopic loss aversion perspectives. Acad Manag J. 2012;55(4):976-997. doi:10.5465/ amj.2011.0211

9. Eberhart AC, Maxwell WF, Siddique AR. An examination of longterm abnormal stock returns and operating performance following R\&D increases. J Finance. 2004;59(2):623-650. doi:10.1111/j.15406261.2004.00644.x

10. Belderbos R, Carree M, Lokshin B. Cooperative R\&D and firm performance. Res Policy. 2004;33(10):1477-1492. doi:10.1016/j. respol.2004.07.003

11. Gómez-Mejía LR, Haynes KT, Núñez-Nickel M, Jacobson KJ, Moyano-Fuentes J. Socioemotional wealth and business risks in family-controlled firms: evidence from Spanish olive oil mills. Adm Sci Q. 2007;52(1):106-137. doi:10.2189/asqu.52.1.106

12. Claessens S, Djankov S, Fan JP, Lang LH. Disentangling the incentive and entrenchment effects of large shareholdings. $J$ Finance. 2002;57(6):2741-2771. doi:10.1111/1540-6261.00511

13. Cronqvist H, Nilsson M. Agency costs of controlling minority shareholders. J Financial Quantit Anal. 2003;695-719. doi:10.2307/ 4126740

14. Sharma P, Chrisman JJ, Chua JH. Strategic management of the family business: past research and future challenges. Fam Bus Rev. 1997;10 (1):1-35. doi:10.1111/j.1741-6248.1997.00001.x

15. Blagoeva R, Mom TJ, Jansen JJ, George G. Problem-solving or selfenhancement? A power perspective on how CEOs affect R\&D search in the face of inconsistent feedback. Acad Manag J. 2019;63 (2):332-355.

16. Quigley TJ, Hambrick DC. Has the "CEO effect" increased in recent decades? A new explanation for the great rise in America's attention to corporate leaders. Strateg Manag J. 2015;36(6):821-830. doi: $10.1002 / \mathrm{smj} .2258$

17. Barker III VL, Mueller GC. CEO characteristics and firm R\&D spending. Manage Sci. 2002;48(6):782-801. doi:10.1287/ mnsc.48.6.782.187 
18. Wu S, Levitas E, Priem RL. CEO tenure and company invention under differing levels of technological dynamism. Acad Manag $J$. 2005;48(5):859-873. doi:10.5465/amj.2005.18803927

19. Bebchuk LA, Cremers KM, Peyer UC. The CEO pay slice. J Financ Econ. 2011;102(1):199-221. doi:10.1016/j.jfineco.2011.05.006

20. Liu Y, Jiraporn P. The effect of CEO power on bond ratings and yields. $J$ Empir Finance. 2010;17(4):744-762. doi:10.1016/j. jempfin.2010.03.003

21. Minichilli A, Corbetta G, MacMillan IC. Top management teams in family-controlled companies:'familiness', 'faultlines', and their impact on financial performance. J Manag Stud. 2010;47 (2):205-222. doi:10.1111/j.1467-6486.2009.00888.x

22. Pérez-González F. Inherited control and firm performance. Am Econ Rev. 2006;96(5):1559-1588. doi:10.1257/aer.96.5.1559

23. Galvin BM, Lange D, Ashforth BE. Narcissistic organizational identification: seeing oneself as central to the organization's identity. Acad Manag Rev. 2015;40(2):163-181. doi:10.5465/amr.2013.0103

24. Hambrick DC, Mason PA. Upper echelons: the organization as a reflection of its top managers. Acad Manag Rev. 1984;9 (2):193-206. doi:10.5465/amr.1984.4277628

25. Habib A, Hossain M. CEO/CFO characteristics and financial reporting quality: a review. Res Account Regul. 2013;25(1):88-100. doi:10.1016/j.racreg.2012.11.002

26. Kouaib A, Jarboui A. The mediating effect of REM on the relationship between CEO overconfidence and subsequent firm performance moderated by IFRS adoption: a moderated-mediation analysis. Res Int Bus Finance. 2017;42:338-352. doi:10.1016/j.ribaf.2017.07.034

27. Miller D, Minichilli A, Corbetta G. Is family leadership always beneficial? Strateg Manag J. 2013;34(5):553-571. doi:10.1002/ smj.2024

28. Miller D, Le breton-miller I. Managing for the Long Run: Lessons in Competitive Advantage from Great Family Businesses. Harvard Business Press; 2005.

29. Miller D, Le breton-miller I. Family governance and firm performance: agency, stewardship, and capabilities. Fam Bus Rev. 2006;19 (1):73-87. doi:10.1111/j.1741-6248.2006.00063.x

30. Gomez-Mejia LR, Cruz C, Berrone P, De Castro J. The bind that ties: socioemotional wealth preservation in family firms. Acad Manag Ann. 2011;5(1):653-707. doi:10.5465/19416520.2011.593320

31. Wiseman RM, Gomez-Mejia LR. A behavioral agency model of managerial risk taking. Acad Manag Rev. 1998;23(1):133-153. doi:10.5465/amr.1998.192967

32. Songini L, Gnan L. Family involvement and agency cost control mechanisms in family small and medium-sized enterprises. $J$ Small Bus Manag. 2015;53(3):748-779. doi:10.1111/jsbm.12085

33. De Massis A, Kotlar J, Campopiano G, Cassia L. The impact of family involvement on SMEs' performance: theory and evidence. J Small Bus Manag. 2015;53(4):924-948. doi:10.1111/jsbm.12093

34. Yan R, Qian X, Xiao S, Li H. The impact of the heterogeneity of family involvement to R\&D investment: the moderating effects of marketization degree and political connections. Entrep Theory Pract. 2019;11:129-138.

35. Chrisman JJ, Chua JH, Pearson AW, Barnett T. Family involvement, family influence, and family-centered non-economic goals in small firms. Entrep Theory Pract. 2012;36(2):267-293. doi:10.1111/j.15406520.2010.00407.x

36. Chen L, Chen H. The clan involvement, the socioemotional wealth and the corporate charitable contributions. Manage World. 2014;8:90-101.

37. Evert RE, Sears JB, Martin JA, Payne GT. Family ownership and family involvement as antecedents of strategic action: a longitudinal study of initial international entry. J Bus Res. 2018;84:301-311. doi:10.1016/j.jbusres.2017.07.019

38. Hsu L, Fournier S, Srinivasan S. Brand architecture strategy and firm value: how leveraging, separating, and distancing the corporate brand affects risk and returns. J Acad Mark Sci. 2016;44(2):261-280. doi:10.1007/s11747-014-0422-5
39. Zhou L. Social responsibility and employees' organizational identification in Chinese family firms. Chin Manag Stud. 2014;8(4):683. doi:10.1108/CMS-11-2012-0159

40. Zahra SA, Hayton JC, Neubaum DO, Dibrell C, Craig J. Culture of family commitment and strategic flexibility: the moderating effect of stewardship. Entrep Theory Pract. 2008;32(6):1035-1054. doi:10.1111/j.1540-6520.2008.00271.x

41. Chrisman JJ, Chua JH, Kellermanns FW, Chang EP. Are family managers agents or stewards? An exploratory study in privately held family firms. J Bus Res. 2007;60(10):1030-1038. doi:10.1016/ j.jbusres.2006.12.011

42. Carney M, Zhao J, Zhu L. Lean innovation: family firm succession and patenting strategy in a dynamic institutional landscape. J Fam Bus Strategy. 2019;10(4):100247. doi:10.1016/j.jfbs.2018.03.002

43. Hambrick D. Upper Echelons Theory: An Update: Academy of Management Briarcliff Manor. NY; 2007.

44. Cannella SFB, Hambrick DC, Finkelstein S, Cannella AA. Strategic Leadership: Theory and Research on Executives, Top Management Teams, and Boards. Oxford U: Strategic Management; 2009.

45. Wang T, Libaers D, Jiao H. Opening the black box of upper echelons in China: TMT attributes and strategic flexibility. J Prod Innov Manag. 2015;32(5):685-703. doi:10.1111/jpim.12152

46. Xu N, Yuan Q, Jiang X, Chan KC. Founder's political connections, second generation involvement, and family firm performance: evidence from China. J Corp Finance. 2015;33:243-259. doi:10.1016/j.jcorpfin.2015.01.004

47. Bennedsen M, Nielsen KM, Pérez-González F, Wolfenzon D. Inside the family firm: the role of families in succession decisions and performance. Q J Econ. 2007;122(2):647-691. doi:10.1162/qjec.122.2.647

48. Cheng Q. Family firm research-a review. China J Account Res. 2014;7(3):149-163. doi:10.1016/j.cjar.2014.03.002

49. Moore DA, Healy PJ. The trouble with overconfidence. Psychol Rev. 2008;115(2):502. doi:10.1037/0033-295X.115.2.502

50. Schumacher C, Keck S, Tang W. Biased interpretation of performance feedback: the role of CEO overconfidence. Strateg Manag J. 2020;41(6):1139-1165. doi:10.1002/smj.3138

51. Ben-David I, Graham JR, Harvey CR. Managerial miscalibration. Q J Econ. 2013;128(4):1547-1584. doi:10.1093/qje/qjt023

52. Malmendier U, Tate G. Does overconfidence affect corporate investment? CEO overconfidence measures revisited. Eur Financial Manag. 2005;11(5):649-659. doi:10.1111/j.1354-7798.2005.00302.x

53. Campbell DF, Guttel WH. Knowledge production of firms: research networks and the" scientification" of business R\&D. Int J Technol Manag. 2005;31(1-2):152-175. doi:10.1504/IJTM.2005.006629

54. Chen SS, Ho KY, Ho PH. CEO overconfidence and long-term performance following R\&D increases. Financ Manag. 2014;43 (2):245-269. doi:10.1111/fima.12035

55. Ahmed AS, Duellman S. Managerial overconfidence and accounting conservatism. J Account Res. 2013;51(1):1-30. doi:10.1111/j.1475679X.2012.00467.x

56. Goel AM, Thakor AV. Overconfidence, CEO selection, and corporate governance. J Finance. 2008;63(6):2737-2784. doi:10.1111/j.15406261.2008.01412.x

57. Schrand CM, Zechman SL. Executive overconfidence and the slippery slope to financial misreporting. $J$ Account Econ. 2012;53(1-2):311-329. doi:10.1016/j.jacceco.2011.09.001

58. Kruger J, Dunning D. Unskilled and unaware of it: how difficulties in recognizing one's own incompetence lead to inflated selfassessments. J Pers Soc Psychol. 1999;77(6):1121. doi:10.1037/ 0022-3514.77.6.1121

59. Weinstein ND. Unrealistic optimism about future life events. $J$ Pers Soc Psychol. 1980;39(5):806. doi:10.1037/0022-3514.39.5.806

60. Jie Z, Youzhi X. The path of influence of corporate governance subject's intervene on corporate diversification: the test of indirect effect based on managerial overconfidence. Nankai Bus Rev. 2011;1:65-74+ 106 . 
61. Liang S. Managers' overconfidence, debt constraints and cost stickiness. Nankai Bus Rev. 2015;18(3):122-131.

62. Lin R, Li F, Olawoyin A. CEO overconfidence and firm internationalization: the moderating role of experience and managerial discretion. Nankai Bus Rev Int. 2020. doi:10.1108/NBRI-08-20190037

63. Block JH. R\&D investments in family and founder firms: an agency perspective. J Bus Ventur. 2012;27(2):248-265. doi:10.1016/j. jbusvent.2010.09.003

64. Bendig D, Foege JN, Endriß S, Brettel M. The effect of family involvement on innovation outcomes: the moderating role of board social capital. J Prod Innov Manag. 2020;37(3):249-272. doi:10.1111/jpim.12522

65. Ramadani V, Memili E, Palalić R, Chang EP. Entrepreneurial Family Businesses. Springer; 2020.

66. Alqatamin RM, Aribi ZA, Arun T. The effect of the CEO's characteristics on EM: evidence from Jordan. Int J Account Inf Manag. 2017;25(3):356-375. doi:10.1108/IJAIM-10-2016-0099

67. Presley TJ, Abbott LJ. AIA submission: CEO overconfidence and the incidence of financial restatement. Adv Account. 2013;29(1):74-84. doi:10.1016/j.adiac.2013.03.007

68. Zhang Y, Rajagopalan N. Once an outsider, always an outsider? CEO origin, strategic change, and firm performance. Strateg Manag J. 2010;31(3):334-346. doi:10.1002/smj.812

69. Hambrick DC, Finkelstein S. Managerial discretion: a bridge between polar views of organizational outcomes. Res Organ Behav. 1987.

70. Yopie S, Itan I. CEO-family vs. CEO-nonfamily: who is a better value creator in family business? J Appl Manag Account Res. 2016;14(2).

71. Hirshleifer D, Low A, Teoh SH. Are overconfident CEOs better innovators? J Finance. 2012;67(4):1457-1498. doi:10.1111/j.15406261.2012.01753.x

72. Griffin D, Tversky A. The weighing of evidence and the determinants of confidence. Cogn Psychol. 1992;24(3):411-435. doi:10.1016/ 0010-0285(92)90013-R

73. Hribar P, Yang H. Does CEO overconfidence affect management forecasting and subsequent earnings management. Unpublished working paper. 2010.

74. Malmendier U, Tate G. Who makes acquisitions? CEO overconfidence and the market's reaction. J Financ Econ. 2008;89(1):20-43. doi:10.1016/j.jfineco.2007.07.002

75. Lin Y-H, Hu S-Y, Chen M-S. Managerial optimism and corporate investment: some empirical evidence from Taiwan. Pac Basin Financ J. 2005;13(5):523-546. doi:10.1016/j.pacfin.2004.12.003

76. Hayward MLA, Hambrick DC. Explaining the premiums paid for large acquisitions: evidence of CEO hubris. Adm Sci Q. 1997;42 (1): 103-127. doi:10.2307/2393810

77. Li J, Tang Y. CEO hubris and firm risk taking in China: the moderating role of managerial discretion. Acad Manag J. 2010;53(1):45-68. doi: $10.5465 / \mathrm{amj} .2010 .48036912$

78. Chen C-J, Lin B-W, Lin Y-H, Hsiao Y-C. Ownership structure, independent board members and innovation performance: a contingency perspective. J Bus Res. 2016;69(9):3371-3379. doi:10.1016/j.jbusres.2016.02.007

79. Diéguez-Soto J, Manzaneque M, González-García V, Galache-Laza T. A study of the moderating influence of R\&D intensity on the family management-firm performance relationship: evidence from Spanish private manufacturing firms. BRQ Bus Res Q. 2019;22 (2):105-118. doi:10.1016/j.brq.2018.08.007
80. Tsao S-M, Lin C-H, Chen VY. Family ownership as a moderator between R\&D investments and CEO compensation. J Bus Res. 2015;68(3):599-606. doi:10.1016/j.jbusres.2014.09.001

81. Jiang F, Jiang Z, Kim KA, Zhang M. Family-firm risk-taking: does religion matter? $J$ Corp Finance. 2015;33:260-278. doi:10.1016/j. jcorpfin.2015.01.007

82. Bozec Y, Di Vito J. Founder-controlled firms and R\&D investments: new evidence from Canada. Fam Bus Rev. 2019;32(1):76-96. doi: $10.1177 / 0894486518793237$

83. Bozec Y, Di Vito J. Founder-controlled firms and R\&D investments: new evidence from Canada. Fam Bus Rev. 2018;0894486518793237.

84. Arellano M, Bond S. Some tests of specification for panel data: Monte Carlo evidence and an application to employment equations. Rev Econ Stud. 1991;58(2):277-297. doi:10.2307/2297968

85. Lim EN. The role of reference point in CEO restricted stock and its impact on R\&D intensity in high-technology firms. Strateg Manag J. 2015;36(6):872-889. doi:10.1002/smj.2252

86. Howard A. (2001). Identifying, assessing, and selecting senior leaders. In S. J. Zaccaro \& R. J. Klimoski (Eds.), The Jossey-Bass business \& management series. The nature of organizational leadership: Understanding the performance imperatives confronting today's leaders (p. 305-346). Jossey-Bass; USA.

87. Zhang Y, Rajagopalan N. When the known devil is better than an unknown god: an empirical study of the antecedents and consequences of relay CEO successions. Acad Manage J. 2004;47 (4):483-500. doi:10.5465/20159598

88. Zajac EJ. CEO selection, succession, compensation and firm performance: a theoretical integration and empirical analysis. Strateg Manag J. 1990;11(3):217-230. doi:10.1002/smj.4250110304

89. Cirillo A, Ossorio M, Pennacchio L. Family ownership and R\&D investment: the moderating role of banks and private equity. Manag Decis. 2019;57(7):1675-1694. doi:10.1108/MD-07-2016-0454

90. Waldkirch M. Non-family CEOs in family firms: spotting gaps and challenging assumptions for a future research agenda. J Fam Bus Strategy. 2020;11(1):100305. doi:10.1016/j.jfbs.2019.100305

91. Mergenthaler R, Rajgopal S, Srinivasan S. CEO and CFO career penalties to missing quarterly analysts forecasts. Available at SSRN 1152421. 2012.

92. Malmendier U, Tate G, Yan J. Managerial Beliefs and Corporate Financial Policies. National Bureau of Economic Research; 2010.

93. Russo JE, Schoemaker PJ. Managing overconfidence. Sloan Manage Rev. 1992;33(2):7-17.

94. Gervais S, Heaton JB, Odean T. Overconfidence, compensation contracts, and labor markets. working paper. Duke University;2009.

95. Bernardo AE, Welch I. On the evolution of overconfidence and entrepreneurs. $J$ Econ Manage Strategy. 2001;10(3):301-330. doi: $10.1162 / 105864001316907964$

96. Wu BH, Mazur M. Managerial incentives and investment policy in family firms: evidence from a structural analysis. J Small Bus Manag. 2018;56(4):618-657. doi:10.1111/jsbm.12308 


\section{Publish your work in this journal}

Psychology Research and Behavior Management is an international, peer-reviewed, open access journal focusing on the science of psychology and its application in behavior management to develop improved outcomes in the clinical, educational, sports and business arenas. Specific topics covered in the journal include: Neuroscience, memory and decision making; Behavior modification and management; Clinical applications; Business and sports performance management; Social and developmental studies; Animal studies. The manuscript management system is completely online and includes a very quick and fair peer-review system, which is all easy to use. Visit http://www. dovepress.com/testimonials.php to read real quotes from published authors. 